
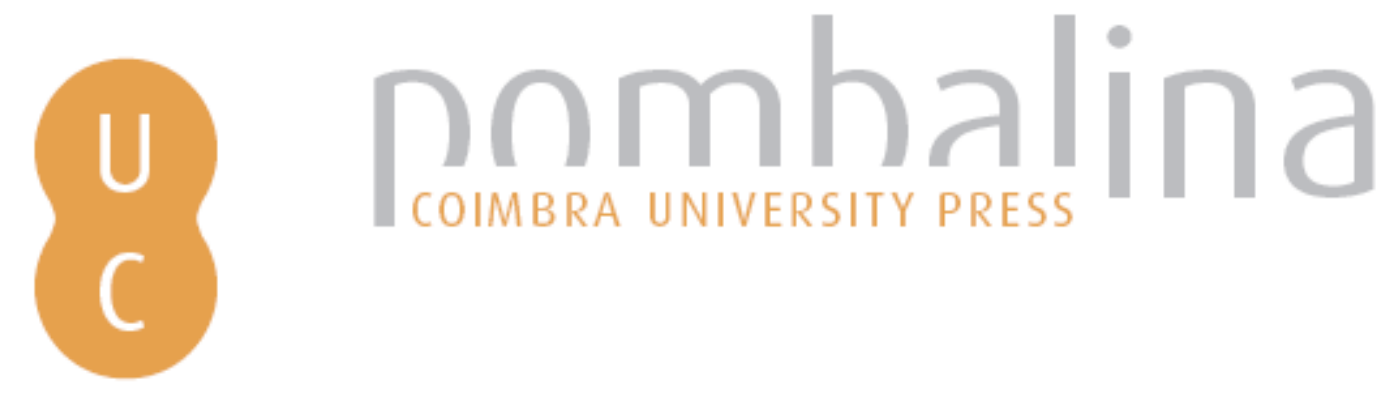

\title{
O contexto museológico da Antropologia na Universidade de Coimbra: uma síntese histórica (1772-1933)
}
Autor(es):
Amaral, Ana Rita; Martins, Maria do Rosário; Miranda, Maria Arminda
Publicado por: Imprensa da Universidade de Coimbra
URL
persistente:
URI:http://hdl.handle.net/10316.2/38516
DOI:
DOI:http://dx.doi.org/10.14195/978-989-26-0610-1_5
Accessed : $\quad$ 26-Apr-2023 14:40:38

A navegação consulta e descarregamento dos títulos inseridos nas Bibliotecas Digitais UC Digitalis, UC Pombalina e UC Impactum, pressupõem a aceitação plena e sem reservas dos Termos e Condições de Uso destas Bibliotecas Digitais, disponíveis em https://digitalis.uc.pt/pt-pt/termos.

Conforme exposto nos referidos Termos e Condições de Uso, o descarregamento de títulos de acesso restrito requer uma licença válida de autorização devendo o utilizador aceder ao(s) documento(s) a partir de um endereço de IP da instituição detentora da supramencionada licença.

Ao utilizador é apenas permitido o descarregamento para uso pessoal, pelo que o emprego do(s) título(s) descarregado(s) para outro fim, designadamente comercial, carece de autorização do respetivo autor ou editor da obra.

Na medida em que todas as obras da UC Digitalis se encontram protegidas pelo Código do Direito de Autor e Direitos Conexos e demais legislação aplicável, toda a cópia, parcial ou total, deste documento, nos casos em que é legalmente admitida, deverá conter ou fazer-se acompanhar por este aviso. 

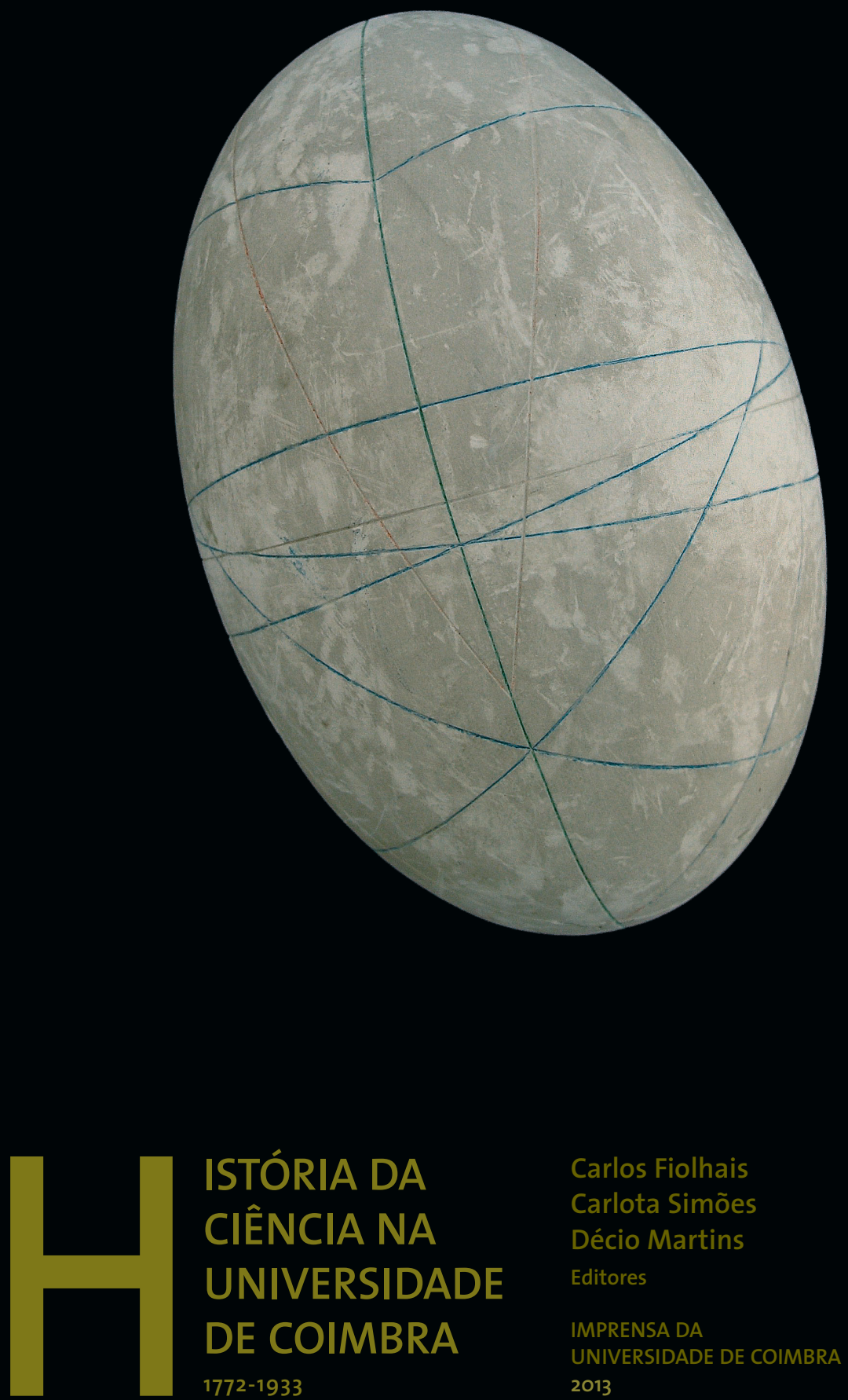

ISTÓRIA DA

CIÊNCIA NA

UNIVERSIDADE

DE COIMBRA

1772-1933
Carlos Fiolhais

Carlota Simões

Décio Martins

Editores

IMPRENSA DA

UNIVERSIDADE DE COIMBRA

2013 
${ }^{1}$ Bolseira da Fundação para a Ciência e Tecnologia. Museu da Ciência da Universidade de Coimbra.

${ }^{2}$ Museu da Ciência da Universidade de Coimbra.

${ }^{3}$ Centro de Investigação em Antropologia e Saúde, Universidade de Coimbra (CIAS).

\title{
O Contexto Museológico da Antropologia na Universidade de Coimbra: Uma SínTese Histórica (1772-1933)
}

\author{
Ana Rita Amaral ${ }^{1}$, Maria do Rosário Martins ${ }^{2-3}$, Maria Arminda Miranda ${ }^{2-3}$
}

\section{INTRODUÇÃO}

O presente texto tem como objectivo enquadrar historicamente uma significativa diversidade de colecções que integram o acervo museológico de antropologia na Universidade de Coimbra, actualmente sob tutela do Museu da Ciência da Universidade de Coimbra. Enquanto trabalho de síntese, pressupõe uma espécie de continuidade histórica que resulta, acima de tudo, de uma interpretação selectiva e documentada dos eventos e da sua relevância. O principal desafio deste exercício está na compreensão das modalidades de classificação destes objectos e no desvelar das suas trajectórias antes e depois da incorporação museológica na Universidade, sendo fundamental reconhecer que as colecções não se encontram todas igualmente documentadas e estudadas. O entendimento destes objectos como "científicos" não é de todo unívoco, apesar de estarmos perante colecções universitárias. Quer isto dizer que, com algumas excepções, se considerarmos a história pré-museológica de muitas das colecções que compóem o anteriormente designado Museu Antropológico da Universidade de Coimbra, verificamos que a sua constituição nem sempre obedeceu àquilo que poderíamos chamar "princípios científicos" (sistematicidade, coerência teórico-demonstrativa, unicidade). Não obstante, a sua transformação em objectos museológico-universitários pode ser considerada suficiente para os revestir desse novo estatuto. Ou seja, depois de entrarem no Museu, estes objectos passaram efectivamente a ser, neste caso, "etnográficos": instrumentos que suportam a construção não só de teorias antropológicas historicamente situadas, como também da própria identidade disciplinar e institucional. Particularmente na Universidade de Coimbra, a designação Museu Ethnographico começa formalmente a ser utilizada apenas a partir de 1881, sendo que as colecçôes que compóem o acervo, como se irá ver, podem eventualmente recuar até ao século XVI ${ }^{1}$.

${ }^{1}$ A complexidade da história da antropologia em Coimbra, primeiro enquanto ciência natural do homem e depois também enquanto ciência colonial, não é objecto deste texto. Para um estudo recente sobre a história da antropologia em Coimbra ver, por exemplo, Santos (2005). 
A abordagem aqui proposta é acima de tudo inclusiva - na medida em que se optou por não excluir colecções cujos critérios de constituição, incorporação e utilização museológica se pudesse julgar menos "científicos" e/ou menos claros - e breve - porque apenas se destacam algumas colecções, remetendo-se para a tabela no anexo n. ${ }^{\circ} 4$ a indicação de todo o acervo incorporado até 1933 . Deste modo, a perspectiva que aqui se apresenta procura traçar uma continuidade do percurso museológico das colecções, assumindo as contradições emergentes de uma abordagem menos normativa, isto é, que não propõe uma grelha de leitura estritamente focada numa pré-definição de "ciência" ou de "colecção científica universitária", seleccionando para esse efeito exclusivamente os elementos materiais que a evidenciariam.

\section{Uma Colecção Antes do Museu? O Núcleo de Armas de Serpe e Morrão DOS SÉculos XV-XVII}

A história das colecções museológicas que viriam a constituir a secção de antropologia do Museu de História Natural pré-data a formação do próprio museu. Esta afirmação é baseada na existência de um núcleo constituído por 39 espingardas de mecha (21 das quais restauradas) e 54 canos respectivos ${ }^{2}$.

A única hipótese quanto à origem destas armas foi avançada em 1872, por Simões de Carvalho, na Memória Histórica da Faculdade de Philosophia (1872: 213-214). Ao descrever o Museu de História Natural da Universidade, Carvalho refere: na primeira [galeria] estão algumas antiguidades, grande porção de armas, que se diz terem servido no glorioso cerco de Diu. A existência deste núcleo de armas na Universidade, bem como a sua hipotética procedência (Cerco de Diu, 1546) volta a ser referida uns anos mais tarde por Belchior da Cruz num artigo intitulado Arcabuzes de serpe e morrão, publicado na Revista Portvgália (Cruz, 1899-1903: 603), mas sem acrescentar informações concludentes. Permanecem até hoje desconhecidos os motivos da incorporação deste núcleo de armas antigas na Universidade de Coimbra e no Museu de História Natural, que só viria a ser constituído em 1772, bem como a razão que conduz à sua permanência na secção de antropologia formalmente constituída no final do século XIX. A documentação analisada não permite sustentar ou afastar a hipótese sugerida, nem ajuda a explicar a função que esta colecção pode ter tido no contexto da Universidade. A sua existência no Museu só começa a ser documentada ao longo do século XIX, através dos inventários antigos ${ }^{3}$. Particularmente no de 1829 , são enumeradas 60 Espingardas antigas com cronhas, e fechos: estes são instrumentos por meio dos quaes isca aceza se chegava ao ouvido da espingarda. Faltão-lhes as varetas; no de 1850, surgem 42 Espingardas de murrao e 48 Canos d'armas antigas e no de 188146 armas de fogo, antigas. Adiciona-se posteriormente a esta colecção, um conjunto de 5 espingardas de pederneira ( 4 restauradas), de fabrico inglês, que muito provavelmente terão perten-

\footnotetext{
${ }^{2}$ As armas de mecha foram substituídas no séc. XV pelas de serpe ou morrão, mas só no séc. XVI se começou a usar este novo processo de inflamação de pólvora (Grande Enciclopédia Portuguesa e Brasileira, 1960: 117), fabricadas e usadas entre os séculos XV e XVII. Tratam-se de armas de cano longo, de carregamento pela boca, cujo processo de funcionamento se baseava numa torcida ardente que, ao ser aproximada da caçoleta por pressão do gatilho, transmitia o fogo ao interior do cano.
}

${ }^{3}$ Apresentados e analisados neste texto. 
cido ao Corpo Militar Académico de Coimbra e sido utilizadas durante as Guerras Peninsulares (1807-1814). Se as primeiras duas referências nos inventários parecem reportar-se exclusivamente às espingardas de mecha, a entrada no inventário de 1881 poderia já incluir estas espingardas de pederneira ${ }^{4}$. Tendo em conta a datação provável associada ao fabrico e utilização destas armas, trata-se do núcleo museológico mais antigo, carecendo ainda de um estudo mais apurado que ajude a melhor contextualizar a sua incorporação e percurso institucional particularmente no contexto do Museu de História Natural.

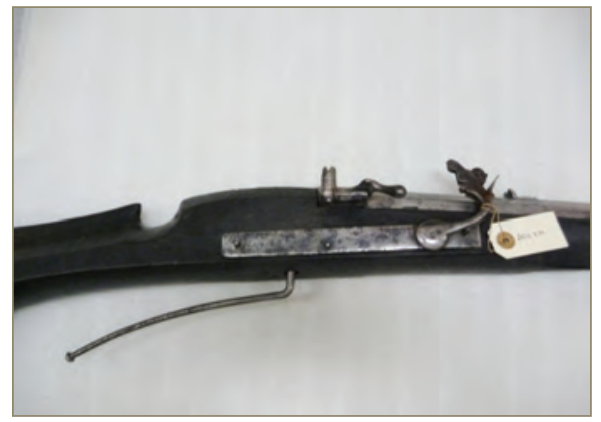

Fig. 1 - Pormenor da espingarda de mecha ANT.2010.3.19.

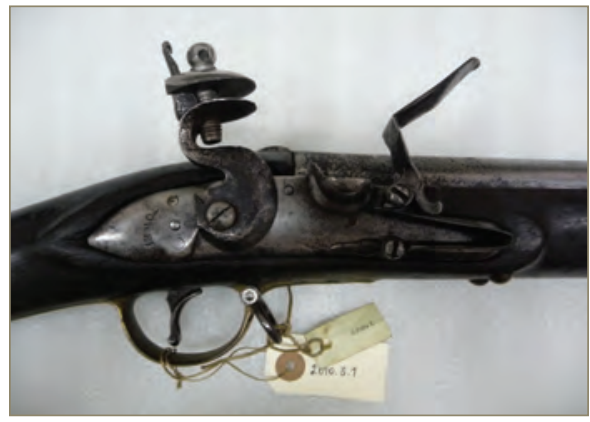

Fig. 3 - Pormenor da espingarda de pederneira ANT.2010.3.1.

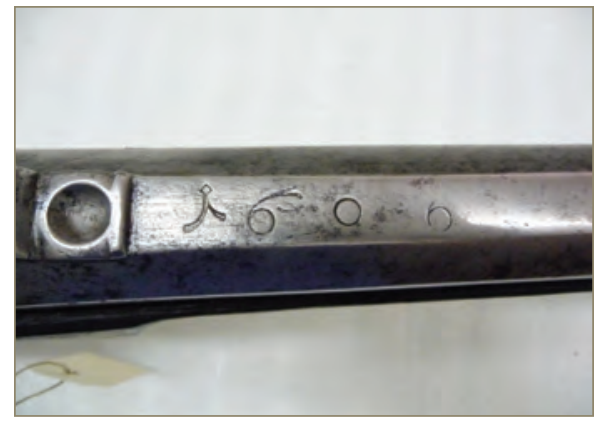

Fig. 2 - Pormenor da inscrição no cano da espingarda de mecha ANT.2010.3.19.

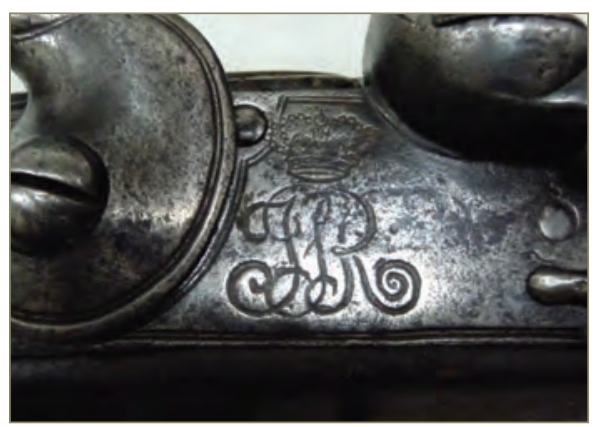

Fig. 4 - Inscrição "JPR» (João Príncipe Regente) da espingarda de pederneira ANT.2010.3.4.

\section{A Criação do Museu de História Natural e as Colecções do Séc. XVIII}

As reformas protagonizadas pelo Marquês de Pombal na Universidade de Coimbra, concretizadas na publicação dos Estatutos em 1772, dão origem a novas pers-

${ }^{4}$ A colecção de armas de fogo antigas foi alvo de um estudo na década de 1980, sob a responsabilidade do então conservador Henrique Coutinho Gouveia e do Arquitecto Armando Almiro Canelhas (especialista em armas antigas). Este trabalho levou à elaboração de um plano de restauro e consequente recuperação de uma parte da colecção pelo Sr. António Luís, então funcionário do Museu Militar de Lisboa. Apenas em 2010 foi realizada a numeração e inventário definitivo da colecção. 
pectivas de encarar e construir a ciência criando-se as Faculdades de Matemática e de Filosofia Natural. Nesta última, constituíram-se como organismos anexos o Museu ou Gabinete de História Natural, o Jardim Botânico, o Gabinete de Física Experimental e o Laboratório Químico. Como os restantes organismos, o Museu era considerado indispensável para a investigação e ensino das ciências naturais a que a reforma concedia particular importância (Gouveia, 1983: 3): nenhuma cousa pode contribuir mais para o adiantamento da História Natural do que à vista contínua dos objectos, que ela comprehende, a qual produz ideias cheias de mais força, e verdade, do que todas as Descripçóes as mais exactas, e as figuras mais perfeitas: He necessário para ficar dignamente o Estudo da Natureza no centro da Universidade, que se faça huma Collecção dos Productos que pertencem aos três Reinos da mesma Natureza (Estatutos $1772)^{5}$. O Museu, após a sua instalação em 1775 no Colégio de Jesus, viria a ocupar as salas do piso superior, incluindo uma sala de aula em anfiteatro e as dedicadas aos três ramos da história natural: mineralogia, botânica e zoologia (Gouveia, 1983: 14). Trata-se de um período, segundo Gouveia (1983: 5), em que se sobrepõe a influência de motivaçôes associadas aos gabinetes das épocas anteriores (raridade e exotismo) às preocupações de análise e observação próprias do espírito científico naturalista que começava a emergir.

É neste contexto que, por determinação régia de 1801, foi estabelecido um programa de correspondência entre o Real Museu da Ajuda e a Universidade de Coimbra, mediante o qual é enviada, em 1806, uma remessa pluridisciplinar de objectos e espécimes para o Museu de História Natural (França, 1922: 87). Na Relação dos Produtos naturais e industriaes que deste Real Museu se remetterão para a Universidade de Coimbra em $1806^{6}$, contam-se 117 objectos de várias proveniências, incluindo África (93), Ásia (16), Índia (1), Nova Hespanha (2) e Peru (5).

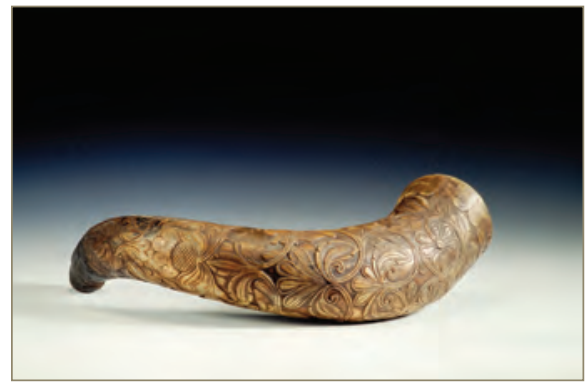

Fig. 5 - Polvorinho em chifre. ANT.Br.84. Índia. Séc. XVIII.

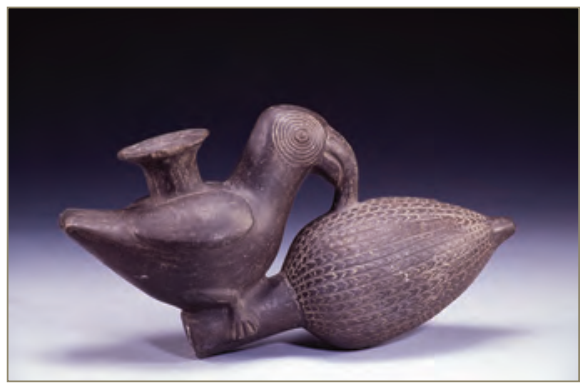

Fig. 6 - Vaso sepulcral. ANT.90.10.265. Peru. Séc. XVIII.

${ }^{5}$ Domenico Vandelli, ao ser empossado como professor da cadeira de História Natural, torna-se também o primeiro responsável pelo Museu.

${ }^{6}$ Documento 26A cujo original pertence ao Arquivo do Museu Bocage, propriedade do Museu Nacional de História Natural. 
No entanto, o enfoque da transferência incide sobre a recolha efectuada por Alexandre Rodrigues Ferreira, entre 1783 e 1792, no decurso da Viagem Philosophica à Amazónia, oriunda maioritariamente do Brasil (321 objectos).

A Relação de 1806 foi metodicamente organizada em torno de sucessivas categorias funcionais indicando, quase sempre e com precisão, sobretudo no que respeita ao Brasil, o local de proveniência, materiais, aspectos particulares da confecção e o correspondente número de exemplares, com a supervisão e o rigor de Ferreira ao introduzir no texto a correcção do que considerava menos claro. As primeiras descriçôes incidem sobre a temática do vestuário marcando a diferença do uso consoante os sexos e revelando interessantes aspectos da tramitação de produtos entre os Gentios da Parte Superior do Rio Branco e os Hollandezes de Surinam. O grupo dos Ornatos dos Gentios; e de alguns Indios Civilisados é bastante numeroso, 146 objectos, dos quais 130 são geográfica e cronologicamente bem diferenciados na Viagem, já que recolhidos entre o Gentio dos rios Negro, Branco e Madeira, mas também, do Gentio Bororó do Rio Paraguay. O capítulo Farças e Mascaras para os Bayles merece especial atenção por se referir a um dos mais notáveis grupos da recolha, persistindo 13 desses objectos embora a Relação não especifique o quantitativo transferido. Pelo breve apontamento que se lhes refere, este conjunto terá vindo para Coimbra antes de 1806: Foram as que ja se remetterão, feitas de entrecascas das Arvores; as quaes lhes servem de papellão, para o pintarem, e fazerem delle as Figuras de varios Animáes.

É consagrada ao Aparelho de tomar tabaco do Gentio do Rio Negro a mais extensa e pormenorizada explicação quanto à descrição dos objectos, materiais, componentes e utilização. Destacamos o Banquinho para assento dos Indios do dito Rio [Rio Negro], de uso exclusivamente masculino e associado às práticas xamanísticas locais, ainda hoje utilizado (Areia et al., 1991(a): 145). O conjunto Armas de Tiro, os Arcos e as Frechas sendo um dos mais numerosos, foi elaborado com algumas preocupações de pormenor, especialmente as Zarabatanas (Areia et al., 2004: 47-48).

A Relação de 1806 coloca interrogações quanto à correspondência numérica entre os objectos mencionados e os existentes. No entanto, é um suporte de trabalho importantíssimo não só para a construção de pontes entre o acervo da antropologia e o espólio alexandrino transferido para Coimbra, como pela identificação das "colecções científicas" mais antigas de que vem a dispor o desenvolvimento da História Natural e da disciplina antropológica na Universidade de Coimbra.

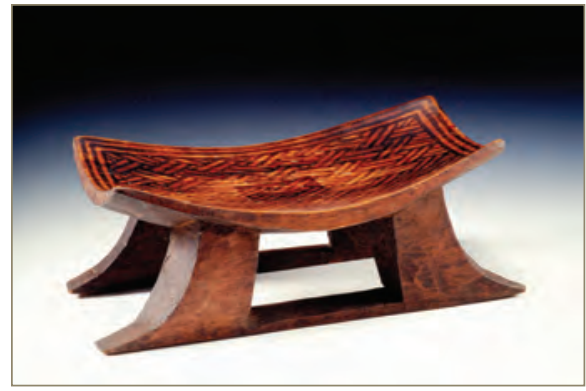

Fig. 7 - Banco cerimonial. ANT.Br.62. Alexandre Rodrigues Ferreira. Séc. XVIII.

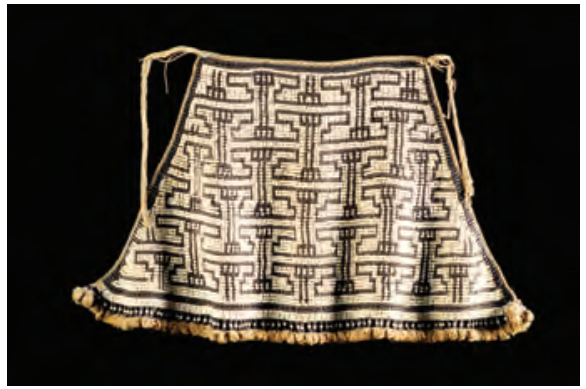

Fig. 8 - Tanga de missangas. ANT.Br.91. Alexandre Rodrigues Ferreira. Séc. XVIII. 
A partida da corte para o Brasil (1807) e a consequente perda de incentivo da Coroa no que respeita à realização de expedições e à constituição de colecções condicionam as primeiras décadas do século XIX, marcadas por um abrandamento da incorporação de objectos no Museu de História Natural da Universidade.

Do ponto de vista da dinâmica museológica interna, os inventários mais antigos actualmente conhecidos datam do século XIX. Estes documentos são importantes para perceber não só a evolução dos conteúdos propriamente ditos do Museu, como também a evolução da sua classificação e da sua disposição no espaço. A catalogação das colecções do Museu de História Natural ter-se-á iniciado pelo menos em 1814 quando foi ponderada a necessidade de uma bibliotheca especial para cada estabelecimento e de um catalogo scientifico do museu (Carvalho, 1872: 86). Não obstante, a primeira relação de inventário conhecida data de 1829, mais de cinquenta anos após a criação do Museu de História Natural. Designado como Sala 5. ${ }^{a}$ - Espingardas antigas. Armas e utensílios dos Índios. Madeiras, cascas, raizes e outros productos vegetaes, consiste no arrolamento enviado em 14 de Outubro de 1829 a José Joaquim Barbosa, doutorado pela Faculdade de Filosofia em 1818 e à data responsável pelo Gabinete de História Natural (Gouveia, 1983: 11; Martins, 1985: 117)7. O documento refere que os objectos se encontravam então na quinta sala do Museu, pendurados e junto às paredes e arrumados em estantes, estando agrupados em três categorias: Antiguidades (referente ao núcleo de armas antigas supra referido), Utensílios dos Índios (ocupando a 5. ${ }^{\mathrm{a}}, 6 .^{\mathrm{a}}$ e $7 .^{\mathrm{a}}$ estantes) e Produtos Vegetais (ocupando a 1. ${ }^{\mathrm{a}}$ estante).

Em 1842 está em preparação um novo processo de inventariação. Simões de Carvalho refere que o Director do Museu foi autorizado a fazer as despesas necessárias para o arranjo do catalogo e inventario do seu estabelecimento e poucos anos mais tarde, em 1849, é encarregado de dirigir o inventário geral do museu de historia natural (Carvalho, 1872: 94; 118). Nesse mesmo ano, quebrando o ritmo praticamente nulo de incorporaçôes ao longo da primeira metade do séc. XIX, a Faculdade de Filosofia lança uma proposta às autoridades e agentes consulares no Ultramar, a fim de se obter remessas de productos para o Museu, acompanhada de instruçôes para a colheita, preparaçôes, acondicionamento e transporte elaboradas para o efeito (Carvalho, 1872: 118), não sendo no entanto conhecidos resultados directos dessas iniciativas.

O novo Inventário do Gabinete de História Natural surge em 1850, assinado a 30 de Julho pelo respectivo Director, Fortunato Rafael Pereira de Sousa. Neste documento é discriminado o conteúdo das dez salas que constituíam o Museu, cabendo agora a 8. ${ }^{\text {a }}$ sala às: Antiguidades. Objectos raros e curiosos, tanto da Arte como da Natureza. Producçoens vegetaes da América e da África. Num pequeno apêndice aparecem listados objectos da África Oriental que posteriormente foram identificados como tendo sido oferecidos em 1850 por João Pedro da Costa Coimbra. Tal como o inventário

${ }^{7}$ Documento manuscrito existente no arquivo das colecções de antropologia, Museu da Ciência da Universidade de Coimbra. Ver anexo n. ${ }^{\circ}$ 1. Trata-se de um documento parcial que de facto apenas indica os conteúdos da referida sala. Desconhecem-se as outras partes do documento que descreveriam as restantes salas do Museu.

${ }^{8}$ Documento manuscrito existente no arquivo das colecções de antropologia, Museu da Ciência da Universidade de Coimbra. Ver anexo n. ${ }^{\circ} 2$. 
anterior, este está organizado em grupos sendo indicado o número total de objectos, não referindo doadores nem datas de aquisição (Gouveia, 1983: 12; Martins, 1985: 118). A análise comparativa dos inventários de 1829 e 1850 traduz uma inexistência de alterações no que respeita à instalação das colecções estando os objectos e produtos vegetais distribuídos por sete armários.

Seria preciso esperar três décadas para ser elaborado o Inventário dos objectos existentes na collecção ethnographica do Museu em Novembro de $1881^{9}$, com o qual passa a dispor pela primeira vez de uma relação em que os objectos são designados como "etnográficos" e na qual surgem numerados tanto colectivamente como individualmente, citando em alguns casos a proveniência, o ano e o doador. Não são dados quaisquer elementos informativos sobre a disposição dos objectos no espaço do Museu. Constata-se, em relação a 1850, um aumento do acervo em resultado da oferta de colecções enviadas por alguns governos coloniais de Macau e Angola, remetidas respectivamente por José Alberto Homem da Cunha Corte Real, Secretário-Geral do Governo de Macau e Timor e Alfredo Augusto Pereira de Melo, Governador de Benguela ${ }^{10}$.

Precisamente entre 1879 e 1882 , várias remessas de objectos e produtos de Macau e Timor deram entrada na Universidade de Coimbra, em resultado de recolhas comissariadas pelo Governo desta província, que tinha como principal objectivo tornar conhecidas as qualidades, aplicaçóes e preços dos produtos com potencial industrial e comercial, por sua vez resultantes dos laços estabelecidos com a Universidade através da figura de Júlio Henriques, então Director do Museu e Jardim Botânico. O seu intento era reforçar a vocação de botânica económica do Museu através da incorporação de produtos vegetais manufacturados. Como o número de objectos existentes no Museu de História Natural que se poderiam adequar a este efeito era, segundo reporta, muito pouco e de não grande qualidade (Henriques, 1883: 60), solicitando às administrações coloniais a expedição de remessas.

Corte Real, que se tinha formado em Coimbra, recebeu-as entusiasticamente ao reconhecer de imediato a utilidade científica das colecçóes que se propunha formar obtendo o apoio do Governador Joaquim José da Graça (Martins, 1999: 248). Nos relatórios publicados no Boletim da Província de Macau e Timor em $1880^{11}$ e no de 1882 ${ }^{12}$, Corte Real (1880: 171) alude precisamente ao facto de Júlio Henriques lhe ter escrito solicitando espécies da flora de Macau e de outra ordem de objectos, por mais insignificantes que parecessem, pequenas amostras de esteiras, tecidos, chapéus entre outros. Ainda que inicialmente as recolhas tivessem sido dirigidas apenas a

\footnotetext{
${ }^{9}$ Documento manuscrito existente no arquivo das colecções de antropologia, Museu da Ciência da Universidade de Coimbra. Ver anexo n. ${ }^{\circ} 3$.

${ }^{10}$ Segundo Júlio Henriques, foi enviada para o Museu Botânico pelo seu amigo Júlio Pereira de Mello uma curiosa colecção de armas, manipansos, fructos e obras de madeira que em Benguela tinha sido reunida por Alfredo Pereira de Mello e que este destinava para o Museu; a maior parte destes objectos foi depois remetida por Henriques para o Museu de História Natural (Henriques, 1881-1882: 252).

${ }^{11}$ Boletim da Província de Macau e Timor, Suplemento ao n. ${ }^{\circ} 26$ de 28 de Junho de 1880

${ }^{12}$ Boletim da Província de Macau e Timor, Suplemento ao n. ${ }^{\circ} 9$ de 8 de Março de 1882.
} 
Macau (1880), a Comissão acabou por estender a obra a Timor ${ }^{13}$ (Corte Real, 1882: 66) cuja riqueza era tão ou mais urgente tornar conhecida.

Embora exista troca de correspondência de 1879 entre Corte Real e Henriques dando conta de diligências para a recolha e envio de plantas para Coimbra, tanto quanto sabemos só em 1880 são mandadas as primeiras remessas de Macau ${ }^{14}$, para o Museu Colonial de Lisboa (entretanto formado em 1871) e para o Museu do Jardim Botânico de Coimbra. Apesar do catálogo referir o total de 578 artefactos, a análise minuciosa da colecção indica tratar-se de um número bastante superior uma vez que agrupa com um só número vários objectos. Em Março de 1882 são expedidos para os Muzeus do Reino (Corte Real, 1883: 17) cerca de 248 exemplares de Timor e 91 de Macau incluindo não só espécies botânicas como, também, artefactos elaborados com matérias naturais daquelas regiōes ${ }^{15}$.

Em Coimbra, as remessas de Macau e Timor foram posteriormente divididas consoante a sua natureza pelos vários gabinetes do Museu de História Natural, tal como afirma Henriques: Além dos objectos que se encontram no Museu Botânico, outros muito importantes foram offerecidos para o Museu de História Natural, taes como aves e outros animais, armas, mineraes... (Henriques, 1883: 65).

No que diz respeito aos espécimes etnográficos, a colecção de Corte Real inclui várias categorias de objectos de uso comum e rituais: móveis, vestuário, acessórios, esculturas de divindades e outros circunscritos à agricultura e pesca fabricados em fibras locais como bambu, rota ${ }^{16}$, junco, ola, algodão e linho.

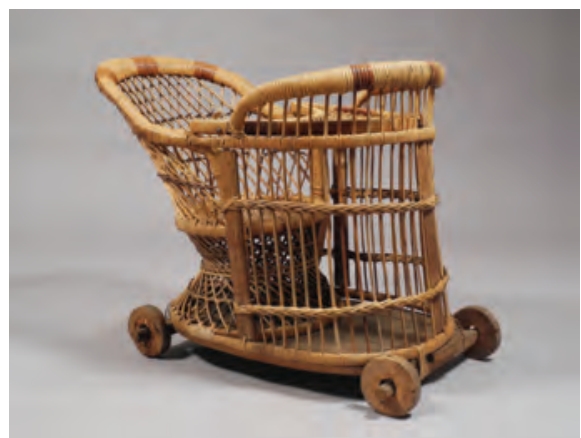

Fig. 9 - Carrinho de bambu. ANT.M.170. José Alberto H. C. Corte Real. Séc. XIX.

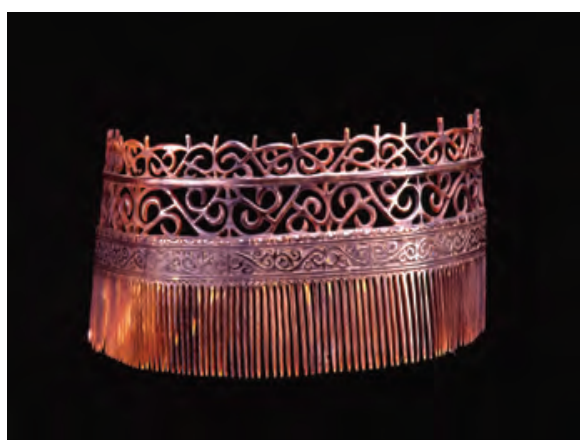

Fig. 10 - Travessa em tartaruga, para cabelo. ANT.T.23. José Alberto H. C. Corte Real. Séc. XIX.

${ }^{13}$ A Relação de objectos enviados para Coimbra (1882) demonstra que a recolha incidiu maioritariamente sobre os três reinos da natureza, recaindo apenas cerca de $34 \%$ sobre espécimes etnográficos.

${ }^{14}$ Remessas enviadas pelo navio Índia e respectivo catálogo que acompanhou a colecção. (http://bibdigital. bot.uc.pt/obras/UCFCTBt-JH-ConDa242-CORREA-JA1/UCFCTBt-JH-ConDa242-CORREA-JA1_item1/ P1.html)

${ }^{15}$ Até 1896, ano em que se viria a autonomizar, Timor fazia parte da Província de Macau.

${ }^{16}$ Corte Real destaca pelo papel que desempenhavam e pela multiplicidade de funçôes duas matérias-primas: a rota e o bambu. 
O Final do Século XiX: A Divisão Disciplinar do Museu e o Incremento das Colecções Etnográficas

O advento de novos ramos de conhecimento nos finais do século XIX e a sua institucionalização universitária determinou em grande medida a criação e desenvolvimento diferenciado de museus dedicados a cada disciplina científica. Paralelamente, a primeira fase da organização de exposiçôes universais, industriais e coloniais tinha-se iniciado em Londres em 1851 intensificando-se à medida que se caminhava para o final do século traduzindo, sobretudo, as preocupações e os esforços de cada nação no que respeitava ao progresso económico, mas tendo como consequência fundamental o reforço das colecções museológicas (Gouveia, 1983: 22). A história museológica e científica da Universidade de Coimbra viria a reflectir em particular estas duas grandes tendências nas últimas décadas de oitocentos.

No que diz respeito à especialização disciplinar e à sua tradução na gestão das colecçóes pertencentes ao Museu de História Natural, verificaram-se as primeiras transferências internas logo em 1870 quando o Museu Botânico começou a ser instalado no Colégio de S. Bento e, em 1873, quando alguns objectos referidos como antiguidades transitaram para o Museu da Secção Archeologica do Instituto (Gouveia, 1983: 16). A criação de uma secção antropológica na Faculdade de Filosofia é mencionada em 1877 num texto de apresentação da Universidade de Coimbra na Exposição Universal de Paris (1878) elaborado pelo Visconde de Villa Maior, Comissário Real da participação portuguesa na exposição ${ }^{17}$.

Com Bernardino Machado a antropologia virá a ser pela primeira vez institucionalizada no contexto universitário português. A proposta de criação da cadeira de antropologia, à qual deveria ser anexada a correspondente secção do Museu, dirigida pelo respectivo Professor, foi apresentada na sessão de 8 de Junho de 1883 da Câmara dos Senhores Deputados. Tornou-se efectiva em 1885, em Carta de Lei, juntamente com a constituição formal das quatro secçōes do Museu de História Natural da Universidade: Zoologia, Botânica, Mineralogia e Antropologia, dirigidas pelos professores das disciplinas (Diário do Governo, 1885) ${ }^{18}$. A cadeira de Anthropologia, Paleontologia Humana e Archeologia Prehistorica foi criada em substituição da de Agricultura e Economia Rural, tornando-se Bernardino Machado responsável pela respectiva secção. Esta nova estrutura, assente na especialização disciplinar e museológica, abolia formalmente a direcção geral do Museu da Faculdade de Filosofia, acentuando significativamente a ligação entre as colecções e o ensino de cada cadeira (Gouveia, 1983: 18).

${ }^{17}$ Villa Maior, 1877: 311.

${ }^{18}$ "Artigo 1. ${ }^{\circ}$ - É supprimida na Faculdade de Philosophia da Universidade de Coimbra, a cadeira de agricultura, zootechnia e economia rural, bem como o ensino da arte de minas.

$\$ 1 .^{\circ}$ - É creada em substituição d'aquella cadeira a de Anthropologia, Paleontologia Humana e Archeologia Prehistorica. (...).

Artigo 2. ${ }^{\circ}$ - O Museu de História Natural da Universidade compõe-se de quatro secções, a saber: secção de Botânica, secção de Zoologia, secção de Mineralogia e de Geologia e secção de Anthropologia e Archeologia Prehistorica.

$\$ 1 .^{\circ}$ - A cada uma dessas secções pertence uma direcção independente e separada, exercida pelo professor da respectiva cadeira (...)» (Cem anos de Antropologia em Coimbra, 1985: 227-228). 
O período que concerne à direcção da secção de antropologia por Bernardino Machado, que se estenderá até 1907, caracterizou-se por um acentuado incremento na incorporação de colecçôes. Neste sentido, a realização da Exposição Insular e Colonial Portugueza de 1894 no Palácio de Cristal no Porto foi um acontecimento chave que este professor soube capitalizar. Em consequência desta exposição foram incorporados mais de mil objectos provenientes maioritariamente de Angola e de Moçambique (Martins, 1985: 126). De acordo com as perspectivas científicas e económicas dos finais do séc. XIX a iniciativa acentuava os sectores comercial, industrial e agricola, destinada a fazer conhecer, o mais exactamente possivel, o estado de adiantamento actual sob qualquer daqueles aspectos, tanto das nossas colónias como das ilhas adjacentes (Catálogo, 1894: XXIV).

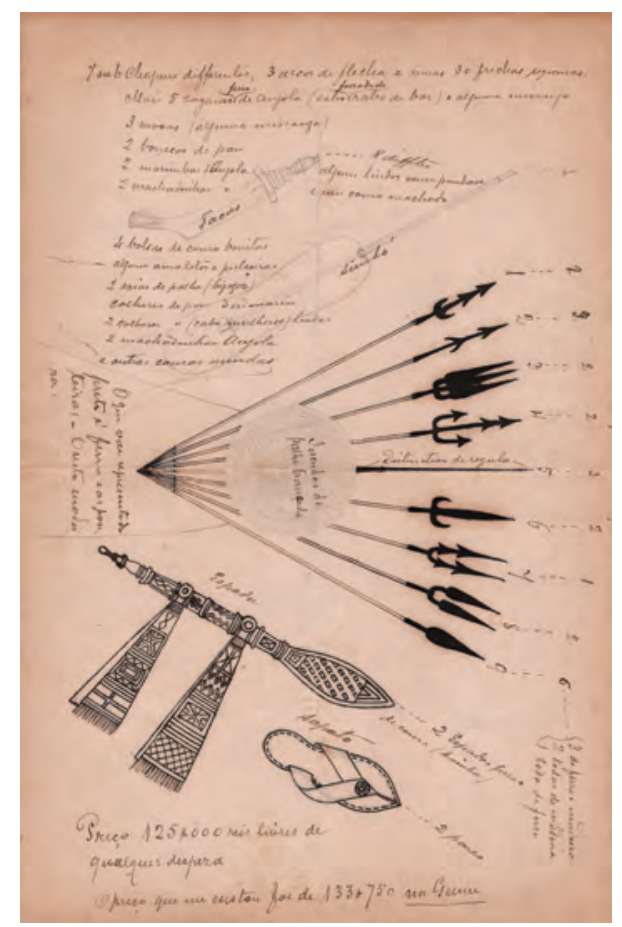

Fig. 11 - Desenho de artefactos da Guiné. Anexo à carta dirigida a Bernardino Machado por António E. F. de Mesquita. Ilha Brava, 29 de Novembro de 1896. Documento manuscrito existente no arquivo das colecçôes de antropologia, Museu da Ciência da Universidade de Coimbra.

A incorporação de objectos e produtos oriundos da Exposição portuense foi, como já referido, consequência da acção de Bernardino Machado mas, também, em grande medida da intervenção de Júlio Henriques. O objectivo deste investigador continuava a ser a obtenção de produtos manufacturados provenientes das regióes tropicais para o Museu Botânico a fim de organizar uma colecção demonstrativa da utilidade das matérias-primas vegetais (Henriques, 1888: VI-VIII). A Bernardino Machado se deveu a inclusão de algumas colecções importantes patentes na Exposição, das quais se destaca a obtenção entre 1896 e 1897, por compra e doação, de 562 objectos da 
colecção de Alberto Correia, maioritariamente de Angola ${ }^{19}$. Tornou-se também responsável pelo sucesso na obtenção de uma colecção constituída essencialmente por armas provenientes de Angola e Guiné, de António E. Ferreira Mesquita, segundo está documentado na correspondência que lhe foi endereçada em 1896, onde é permissível a identificação dos objectos.

Talvez em resposta ao elevado número de incorporações e a uma correspondente necessidade de actualização dos inventários, em 1897 começou a ser publicado na revista $O$ Instituto, sob o título Catálogo do Museu Ethnographico da Universidade de Coimbra, um inventário detalhado dos objectos então existentes no museu, incluindo a maioria dos entrados até à data, da autoria de Adolpho Frederico Moller, jardineiro chefe interino do Jardim Botânico. Apesar de incompleto (porque exclui as colecções do Brasil, Macau e Timor), este trabalho segue um critério geográfico, agrupando 1.221 exemplares de Cabo Verde, Guiné, Dahomé e Ajudá ${ }^{20}$, Ilha do Príncipe e de S. Tomé, Congo Francês ${ }^{21}$ e parte da colecção de Angola, de acordo com as características funcionais. Moller atribuiu-lhes ainda um número individual, designação, dimensões, grupo étnico, proveniência, ano de aquisição e identidade do anterior proprietário.

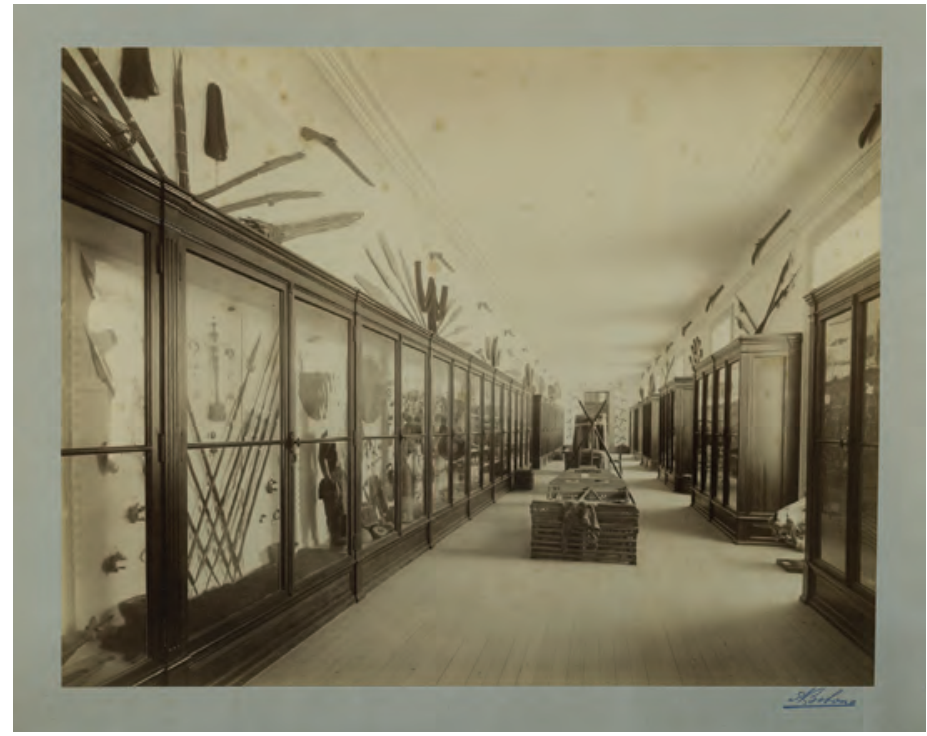

Fig. 12 - Perspectiva de uma das salas de etnografia do Colégio de Jesus. A. Bobone, 1899. Documento existente na Biblioteca da Antropologia, Departamento de Ciências da Vida da Universidade de Coimbra.

${ }^{19} \mathrm{O}$ coleccionador Alberto Correia participou na Exposição Insular e Colonial já depois do seu regresso definitivo de Angola, onde vivera cerca de cinco anos como funcionário dos caminhos-de-ferro. O catálogo dessa realização inclui observações feitas por este expositor acerca dos diferentes produtos artificiais dos indígenas que apresentou, em que transcreve diversos passos do livro Angola e Congo, que F. A. Pinto publicara em 1888 (Gouveia, 1983: 25, nota 2).

${ }^{20}$ Actual Benim.

${ }^{21}$ Território actualmente compreendido entre a República do Congo, o Gabão e a República Centro-Africana. 
Nesta época, as instalações ocupadas pela secção de antropologia, ainda localizada no Colégio de Jesus, nomeadamente as salas de exposição das colecções, são conhecidas através de dois conjuntos fotográficos. Segundo Gouveia (1985: 502), o primeiro foi executado para a apresentação da Universidade no Congresso Pedagógico efectuado em Madrid (1892), tendo o segundo sido realizado pelo fotógrafo lisboeta A. Bobone, em 1899, para a representação da Universidade na Exposição Universal de Paris de 1900.

É possível reconhecer nesta imagem algumas espingardas de serpe e de morrão (núcleo antigo) dispostas sequencialmente junto ao tecto, enquanto outros objectos se encontram organizados em conjuntos temáticos exibidos em panóplia tendo subjacente uma preocupação estética.

A transição para o séc. XX foi indubitavelmente um período de forte incremento das colecçōes etnográficas do Museu de História Natural. Se em 1878 a Ethnographia repartia-se no Museu por apenas 12 metros de estantes, como afirmava Júlio Henriques (1911: 2-5), à data da implantação da República ocupavam as collecçôes ethnographicas estantes de 63 metros, já muito insuficientes; e as colecçôes anthropologicas, começadas já depois de 1885, mal cabem em quatro salas ${ }^{22}$. Inclusive, entre 1897 e 1905 Bernardino Machado em ofícios dirigidos ao Reitor propôs a expansão do museu: Havendo toda a conveniência em ampliar os locais do Museu de Ethnografia para que possa expor-se proveitosamente à vista de alunos e visitantes o numeroso material de estudo que elle hoje já possue..., utilizando-se o edifício da Igreja de S. Boaventura e respectivo claustro (Miranda, 1985: 210).

\section{As Primeiras Décadas do Séc. XX}

A reforma dos Estudos Universitários de 1901 dividiu as cadeiras da Faculdade de Filosofia em duas secçōes: Sciencias Physico-Chimicas e Sciencias Historico-Naturais. A Antropologia passou a ser a $10^{\text {a }}$ cadeira do Curso Geral da Faculdade de Philosophia, Seç̧ão Sciencias Historico-Naturais, estando a ela ligado o Museu Antropológico definido como estabelecimento anexo à Faculdade Philosophia (Areia et al, 1991: 92).

Bernardino Machado vem a pedir, em 1907, por razões políticas, a exoneração do cargo de professor catedrático, sendo substituído por Eusébio Tamagnini, cujos interesses académicos conduziriam à secundarização da etnografia ao longo de toda a primeira metade do século XX em prol de um desenvolvimento pragmático da antropologia física (Porto, 2009: 86).

As três maiores colecções incorporadas já no séc. XX foram, a comprada a José Maria Carvalho e Rego (1902), proveniente de Moçambique, constituída essencialmente por adornos, instrumentos musicais e armas gentílicas ( 245 objectos); as colecções oferecidas por Francisco Xavier Cabral de Moncada (1902) e José Pinto Meira

${ }^{22}$ Por colecçōes antropológicas, Júlio Henriques referia-se às colecçōes de antropologia física constituídas por iniciativa de Bernardino Machado, na mesma altura da fundação da cadeira de antropologia, designadamente as colecções de crânios de Timor (1883), a colecção de cabeças frenológicas (1890), colecções osteológicas humanas identificadas das três Escolas Médicas (1898-1903), entre outras (Rocha, 1995: 9-15). Uma vez que a dinâmica institucional recente condicionou a concepção e gestão diferenciada destas colecções em relação às colecções etnográficas, aquelas não foram consideradas neste texto. 
(1916), ambas de Angola, incluindo esculturas, cachimbos, caixas de rapé, adornos, pentes, utensílios de cozinha, cestaria, símbolos do poder.

Note-se que em 1902 a existência de colecções etnográficas não servia apenas a área museográfica, uma vez que também eram motivo de estudo associadas ao ensino, como está patente nos trabalhos dos alunos, ilustrados nas Dissertaçóes para a cadeira de Anthropologia.

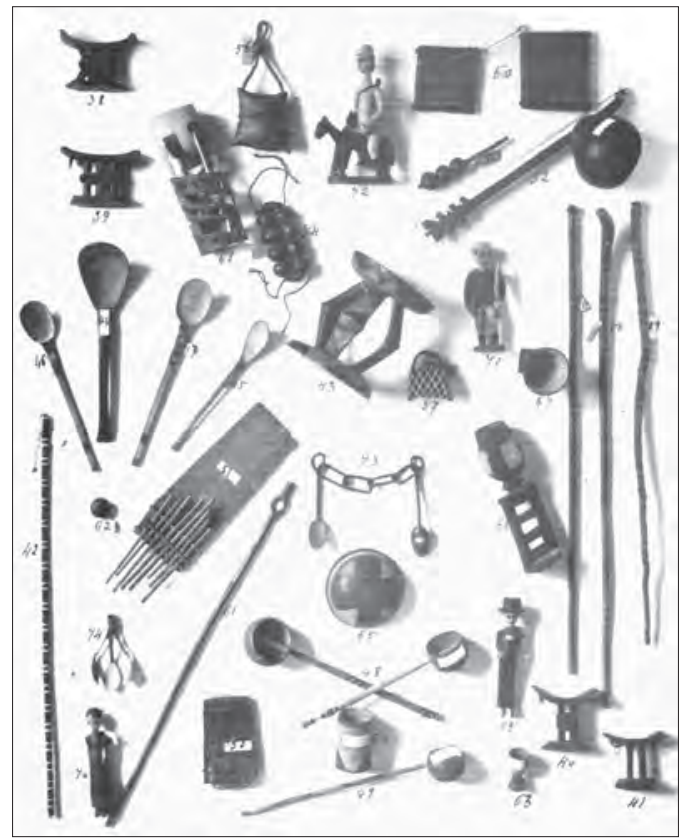

Fig. 13 - Ilustração do trabalho Indístria-Moçambique, elaborado por Carlos Acciaioli da Fonseca Themudo, incluído nas Dissertaçōes para a cadeira de Anthropologia, 1902. Documento existente no arquivo da Antropologia, Departamento de Ciências da Vida da Universidade de Coimbra.

Após a resignação de Bernardino Machado, Tamagnini passou a dirigir o Museu de Antropologia (1907-1950) direccionando a sua actividade para a investigação traduzida, como ele próprio afirmara, no ensino da Antropologia Física. Elabora e publica um Programa de Antropologia dividido entre Antropologia Zoológica, que inclui secçōes como Morfologia comparada das raças humanas ou Paleontologia dos Primatas e Antropologia Etnológica, composto por três secções, O grupo Euro-asiático; sua extensão e variabilidade; subdivisão de Kolmann, Origens europeias e Problemas sociais (Tamagnini; Serra, 1942: 7).

Um dos elos mais importantes entre esta linha de actuação e o estudo das colecções foi concretizado com o Curso Livre de Etnografia Colonial (1912-1913), programado e leccionado por Barros e Cunha, que procurava promover a investigação das populações das colónias de África, Índia, Macau e Timor pela importância do conhecimento exacto da etnografia dos indígenas das colónias quanto à sua composição étnica e etnografia: costumes, religiōes, artes, linguística, etc. sendo as colecções um recurso para o estudo do plano a leccionar (Tamagnini; Serra, 1942). 
Em 1911, com a reforma da Universidade de Coimbra, as Faculdades de Matemática e Filosofia deram lugar à Faculdade de Ciências, ficando o Museu Antropológico associado a esta Faculdade. A transferência das colecções do Colégio de Jesus para o de S. Boaventura (Rua Larga), onde irá permanecer durante cerca de 40 anos, viria a ocorrer já nos finais da segunda década do séc. XX.

Nos anos seguintes regista-se um significativo crescimento do acervo do Museu devido à incorporação das colecções pertencentes a Horácio Paulo Menano (1923), José Francisco Nazaré (1924), Eduardo Gomes Martins Cardoso (1927) e à recolha de Luiz Wittnich Carrisso (1927), todas provenientes de Angola e Moçambique.

Pela relevância de que se revestiram as Missões Botânicas realizadas em Angola, entre 1927 e 1937, levadas a cabo por Carrisso, professor de botânica na Universidade de Coimbra, destaca-se particularmente a primeira uma vez que resultou num aumento do espólio com interesse etnográfico enriquecido, por vezes, com documentação iconográfica contida no inventário que testemunha a transferência de 78 objectos para o Museu Antropológico ${ }^{23}$. Desconhece-se a data e o autor do documento, pressupondo-se que a colecção terá sido organizada no Museu Botânico e, posteriormente, incorporada na antropologia. Este facto advém da observação feita na nota de rodapé escrita a vermelho, com caligrafia diferente, referindo que os dígitos inscritos naquela cor foram colocados com base nos números de inventário atribuídos ${ }^{24}$ no Catálogo das colecçôes etnográficas, publicado em 1955 (Amorim; Morais, 1955). A análise deste manuscrito sugere-nos o destaque das armas de caça e cerimoniais, perfazendo um total de $44 \%$, sendo que $26 \%$ incluem-se na categoria de arcos e flechas, utensílios mágico-religiosos e o conjunto de cinco máscaras recolhidas no Nordeste da Lunda, em madeira e entrecasca de árvore batida. Carrisso apenas descreve a forma como o toucado da máscara Mwana Pwo é obtido: o cabelo aglomerado com argila vermelha é óleo de rícino forma pequeninas massas ovóides e esféricas, penteado que imita com fidelidade o das mulheres Cokwe. Um outro raro e excelente exemplar, máscara $N k a k i$, da etnia Lwalwa, proveniente da região do Kasai apresenta uma forte linguagem visual com a característica marca edjindula o kankolo, tacha de latão à guisa de botão no topo do nariz, tipicamente um símbolo Nkaki. Dada a importância atribuída ao emprego de cachimbos de água para fumar makanya, Carrisso desenhou uma mutopa descrevendo algumas das partes componentes deste artefacto $^{25}$, utilizado colectivamente em audiências públicas, primeiramente fumado pelos chefes e depois pelos súbditos, entre anciāos, amigos ou parentes ou em rituais onde o adivinho oferece baforadas ao espírito do seu ngombo ya cisuka para que ele se revele propício à sessão (Bastin, 2010: 223).

${ }^{23}$ No documento da Relação de 1927 foram incluídos dois Muquiches, apesar de terem sido recolhidos aquando da Missão Académica realizada em 1929.

${ }^{24}$ Note-se que nem sempre esta numeração está correcta em relação aos objectos recolhidos por Carrisso.

${ }^{25}$ De acordo com Carrisso os termos foram aplicados "segundo a língua quioca de Saurimo". 


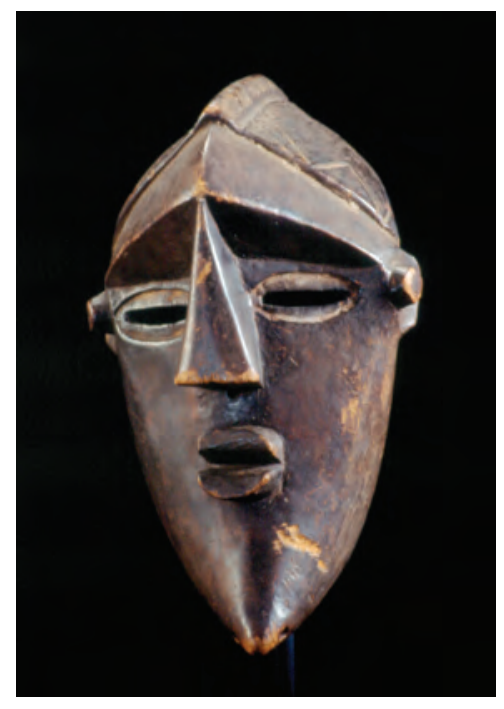

Fig. 14 - Máscara ritual. Nkaki. ANT. Ang.270. L. Carrisso, 1927.

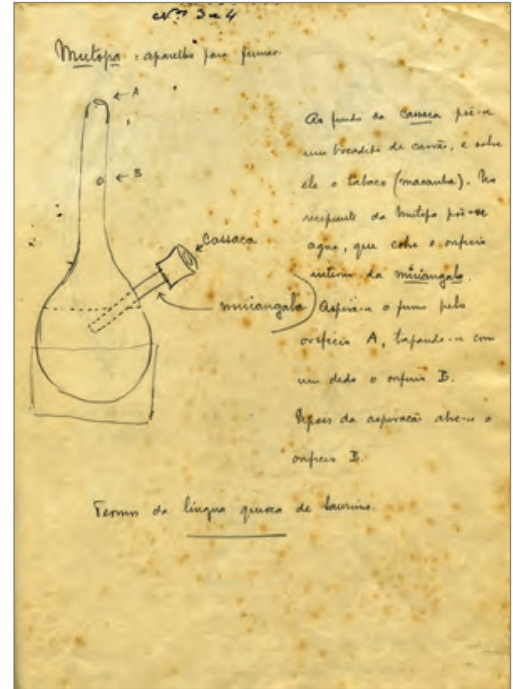

Fig. 15 - Desenho de Luís W. Carrisso que integrou a lista de objectos da Missão Botânica de 1927. Documento manuscrito existente no arquivo das colecções de antropologia, Museu da Ciência da Universidade de Coimbra.

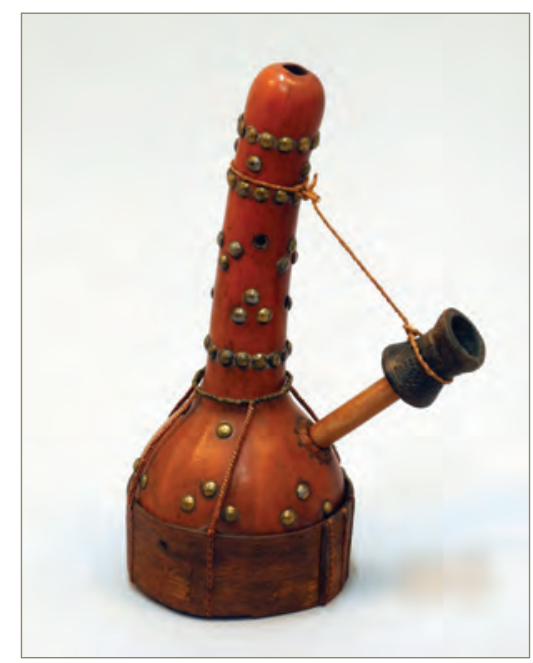

Fig. 16 - Cachimbo d'água. Mutopa. ANT.Ang.166. L. Carrisso, 1927.

\section{CONClusão}

Nos séculos XIX e XX, o Museu de História Natural da Universidade de Coimbra recebeu diversas colecçôes em consequência de expediçôes científicas e em resultado de redes pessoais e institucionais estabelecidas ao longo do tempo. Assim, os acer- 
vos analisados tanto resultaram de processos de recolha sistemática com fins científicos como de outros contextos. Colecçóes privadas, designadamente as que estiveram patentes nas exposiçôes universais e coloniais, vieram a ser incorporadas no âmbito museológico universitário, transformando-se em patrimónios científicos.

Foram inquestionáveis as marcas deixadas pela actuação de determinadas personalidades ao contribuírem para a história e percurso das colecções antropológicas da Universidade de Coimbra:

Alexandre Rodrigues Ferreira tornou-se um dos mais destacados naturalistas da sua época, por formação académica e pela prática profissional projectada nos seus escritos e no vastíssimo espólio colectado no decurso da Viagem Philosophica (1783-1792);

Júlio Henriques, segundo o qual um Jardim Botânico deveria reunir uma colecção demonstrativa da utilidade das matérias primas vegetais, endereçou pedidos às administraçôes coloniais para envio de remessas que acabaram por se traduzir num aumento dos acervos das várias secçōes do Museu de História Natural;

José Alberto H. C. Corte Real, natural de Coimbra e formado em Direito pela mesma Universidade, cujo empenho e dinâmica o levou a reconhecer a proposta que lhe foi apresentada por Júlio Henriques reunindo amostras das riquezas que abundavam em Macau e Timor de modo a conseguir o melhor para ser exposto nos museus;

Bernardino Machado, promotor da criação da cadeira de Antropologia (1885), soube igualmente tirar partido da sua influência pessoal e relaçôes institucionais para reforçar e ampliar o Museu de Ethnographia;

Luiz Wittnich Carrisso, sucessor de Júlio Henriques, deu a conhecer, sob diversas perspectivas, o designado país de além-mar demonstrando o potencial científico disponível nos territórios coloniais.

A pesquisa histórica que permite contextualizar melhor as dinâmicas que nortearam a recolha destas colecções, na maioria alicerçadas por redes que incluíam ex-alunos e docentes da Universidade Coimbra, sendo um trabalho aberto à discussão e em constante progresso, permite-nos perspectivar as contingências da construção de saberes antropológicos associados a objectos cuja classificação e função deve ser compreendida tanto a partir da sua vida pré como pós museológica. O ciclo que vai da constituição do Museu de História Natural da Universidade no século XVIII até ao primeiro terço do século XX, permanece uma época notável da história da ciência museológica em Coimbra uma vez que se torna possível captar uma certa continuidade no que respeita ao ritmo de incorporaçôes e concomitante desenvolvimento científico e disciplinar. A apresentação da colecção de armas antigas, que antecede a formação do museu, teve como objectivo desestabilizar a continuidade que firma a história do museu apenas a partir da sua constituição formal, fazendo-a recuar e incluir as interrogações associadas ao ingresso e função museológica da referida colecção. Por outro lado, à medida que se avança nas primeiras décadas do século XX, esta continuidade voltaria a ser abalada, com o museu ao perder progressivamente a capacidade de acompanhar os progressos das disciplinas correspondentes, ainda que nalguns casos tenha desempenhado outro tipo de funções no contexto da Universidade.

A exploração da complexidade das razões subjacentes a esta afirmação, bem como as constantes reformulações institucionais que o museu tem sofrido, extravasam o âmbito cronológico deste texto e, como tal, ficam como mote para uma reflexão crítica acerca do papel actual das colecções científicas e dos museus universitários. 


\section{Bibliografia}

AMORIM, Fernando Bayolo P.; MORAIS, Maria Helena Xavier de. 1955. Catálogo Inventário do Museu de Etnografia do Ultramar do Instituto de Antropologia da Universidade de Coimbra. Estudos de Etnologia, Anais, Vol. X, Tomo I. Lisboa, J. M. G. I. U.

AREIA, M. Laranjeira; ROCHA, M. Augusta; MIRANDA, M. Arminda. 1991. O Museu e Laboratório Antropológico da Universidade de Coimbra. In: Universidade(s), História, Memórias, Perspectivas. Coimbra, Congresso de História da Universidade, Vol. II: 87-105.

AREIA, Manuel L. R. de; MIRANDA, Maria A; HARTMANN, Thekla. 1991 (a). Memória da Amazónia. Coimbra, Museu e Laboratório Antropológico da Universidade de Coimbra.

AREIA, M. Laranjeira; MIRANDA, M. Arminda; MARTINS, M. Rosário. 2004. Viagem ao Brasil de Alexandre Rodrigues Ferreira. Colecção Etnográfica. Vol. II. Lisboa, Kapa Editorial.

BASTIN, Marie Louise. 2010. Arte Decorativa Cokwe. Coimbra, Museu Antropológico da Universidade de Coimbra e Museu do Dundu, Vol. I e II.

Boletim da Provincia de Macau e Timor, Suplemento ao n. ${ }^{\circ} 26$ de 28 de Junho de 1880.

Boletim da Provincia de Macau e Timor, Suplemento ao n.o 9 de 8 de Março de 1882.

CARVALHO, Joaquim Augusto Simões de. 1872. Memória Histórica da Faculdade de Philosophia. Coimbra, Imprensa da Universidade.

Catálogo da Exposição Insular e Colonial Portugueza. 1894. Palácio de Crystal Portuense. Lisboa. Imprensa Nacional (capa 1896).

Cem Anos de Antropologia em Coimbra: 1885-1985. 1985. Cronologia. Coimbra, Museu e Laboratório Antropológico.

CORTE REAL, José Alberto H. C. 1879. [Carta], 1879 Fev. 25, Macau, a Júlio Henriques, Coimbra [manuscrito] [1] f. ; $22 \times 27 \mathrm{~cm}$ dob. em $22 \times 14 \mathrm{~cm}$. UCFCT Botânica Fundo JH - Pasta Con-Da (242) [http://bibdigital.bot.uc.pt/obras/UCFCTBt-JH-Con Da242-CORREA-JA1/UCFCTBt-JH-ConDa242-CORREA-JA1_item1/P1.html]

CORTE REAL, José Alberto H. C. 1880. Relatório. Boletim da Província de Macau e Timor de 28 de Junho de 1880. Suplemento ao n. ${ }^{o}$ 26: 177-184.

CORTE REAL, José Alberto H. C. 1882. Relatório. Boletim da Provincia de Macau e Timor de 8 de Março de 1882. Suplemento ao n. ${ }^{\text {9: 66-77. }}$

CORTE REAL, José Alberto H. C. 1883. Macau e Timor. Remessa de Productos. Exposição em Macau. In: O Instituto. Coimbra, Imprensa da Universidade, Vol. XXX: 15-26.

CRUZ, Pedro Belchior. 1899-1903. Arcabuzes de serpe e morrão. In: Revista Portugália, Porto, Tomo I: 603-604.

Diário do Governo. 1885. Carta de Lei de 2 de Julho, D. G. n. ${ }^{\circ} 149,9$ de Julho.

Estatutos Da Universidade De Coimbra (1772). 1972. Coimbra, Universidade de Coimbra. Livro III. (II Centenário da Reforma Pombalina).

FRANÇA, Carlos. 1922. Doutor Alexandre Rodrigues Ferreira (1756-1815). História de uma Missão Scientífica ao Brasil no séc. XVIII. In: Boletim da Sociedade Broteriana, Coimbra, Vol. I, II Série: 65-123.

GOUVEIA, H. Coutinho. 1983. Colecções angolanas no Museu e Laboratório Antropológico da Universidade de Coimbra: uma perspectiva histórica. Lisboa, Comunicação apresentada na Sociedade de Geografia de Lisboa. Comemoração do Meio Milénio da Descoberta do Congo. 
GOUVEIA, H. Coutinho. 1985. Colecções africanas do Museu e Laboratório Antropológico da Universidade de Coimbra: uma perspectiva histórica. In: Bibliotecas, Arquivos e Museus. Lisboa, I. P. P. C., Vol. 1, n.o 2, Julho a Dezembro: 485-532.

Grande Enciclopédia Portuguesa e Brasileira.1960. Lisboa, Editorial Enciclopédia, Vol. III.

HENRIQUES, Júlio. 1881-1882. Museu Botânico. In: Anuário da Universidade de Coimbra. Coimbra, Imprensa da Universidade: 245-255.

HENRIQUES, Júlio. 1883. O Museu Botânico da Universidade e as Collecçóes de Productos de Macau e Timor. In: O Instituto, Vol. XXX, n. ${ }^{\circ}$ 2. Coimbra, Imprensa da Universidade: 60-65.

HENRIQUES, Júlio. 1888. A Universidade de Coimbra. O Museu Botânico. In: Anuário da Universidade de Coimbra. Coimbra. Imprensa da Universidade: IV-XIX.

HENRIQUES, Júlio. 1911. Universidade de Coimbra. In: Coimbra Pittoresca. Coimbra, ano 1, n. ${ }^{\circ}$ 6, Setembro: 2-5.

MARTINS, Maria do Rosário. 1985. Colecções Etnográficas. In: Cem Anos de Antropologia em Coimbra: 1885-1985. Coimbra, Instituto de Antropologia: 117-148.

MARTINS, Maria do Rosário. 1999. Timor na colecção do Museu Antropológico da Universidade de Coimbra. In: Os Espaços de um Império. Porto, C. N. C. D. P.: 239-250.

MIRANDA, Maria Arminda. 1985. Extensão Cultural. In: Cem Anos de Antropologia em Coimbra: 1885-1985. Coimbra, Instituto de Antropologia: 209-226.

PORTO, Nuno. 2009. Modos de objectificação da dominação colonial: o caso do Museu do Dundo, 1940-1970. Lisboa, Fundação Calouste Gulbenkian, Fundação para a Ciência e Tecnologia.

ROCHA, Maria Augusta. 1995. Les collections ostéologiques humaines identifiées du Musée Anthropologique de l'Université de Coimbra. In: Antropologia Portuguesa. Coimbra, Instituto de Antropologia, Vol.13: 7-38.

SANTOS, Gonçalo Duro dos. 2005. A Escola de Antropologia de Coimbra, 1885-1950: o que significa seguir uma regra cientifica? Lisboa, Imprensa de Ciências Sociais.

TAMAGNINI, E.; Serra, J. A. 1942. Subsidios para a História da Antropologia Portuguesa. Coimbra, Congresso da Actividade Científica Portuguesa.

VILLA MAIOR, Visconde. 1877. Exposição succinta da organização actual da Universidade de Coimbra precedida de uma breve notícia histórica d'este estabelecimento. Coimbra, Imprensa da Universidade. 
ANEXo N. ${ }^{\circ}$ 1. INVENTÁRIO De $1829^{26}$

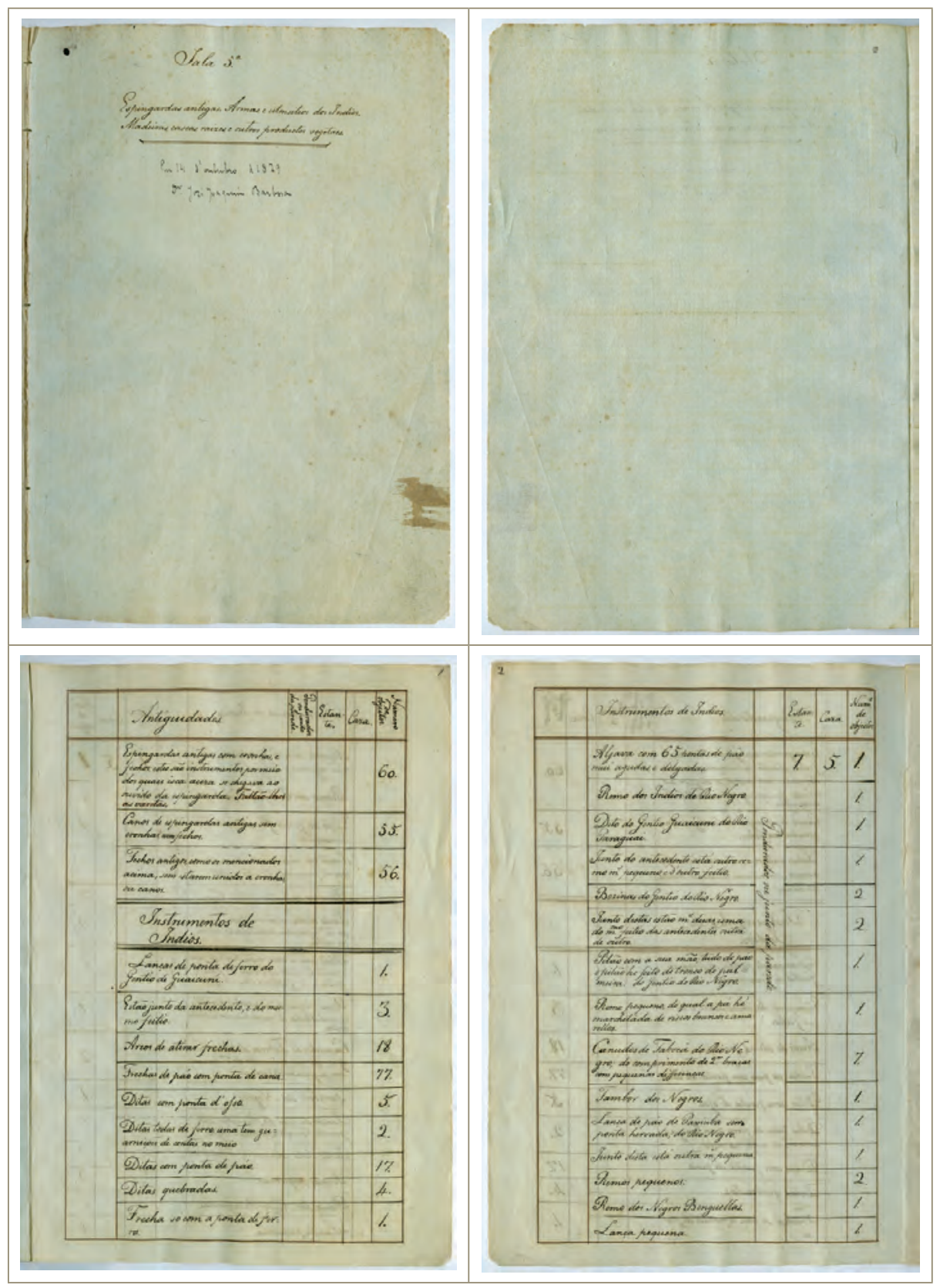

${ }^{26}$ Documento manuscrito existente no arquivo das colecções de antropologia, Museu da Ciência da Universidade de Coimbra. 


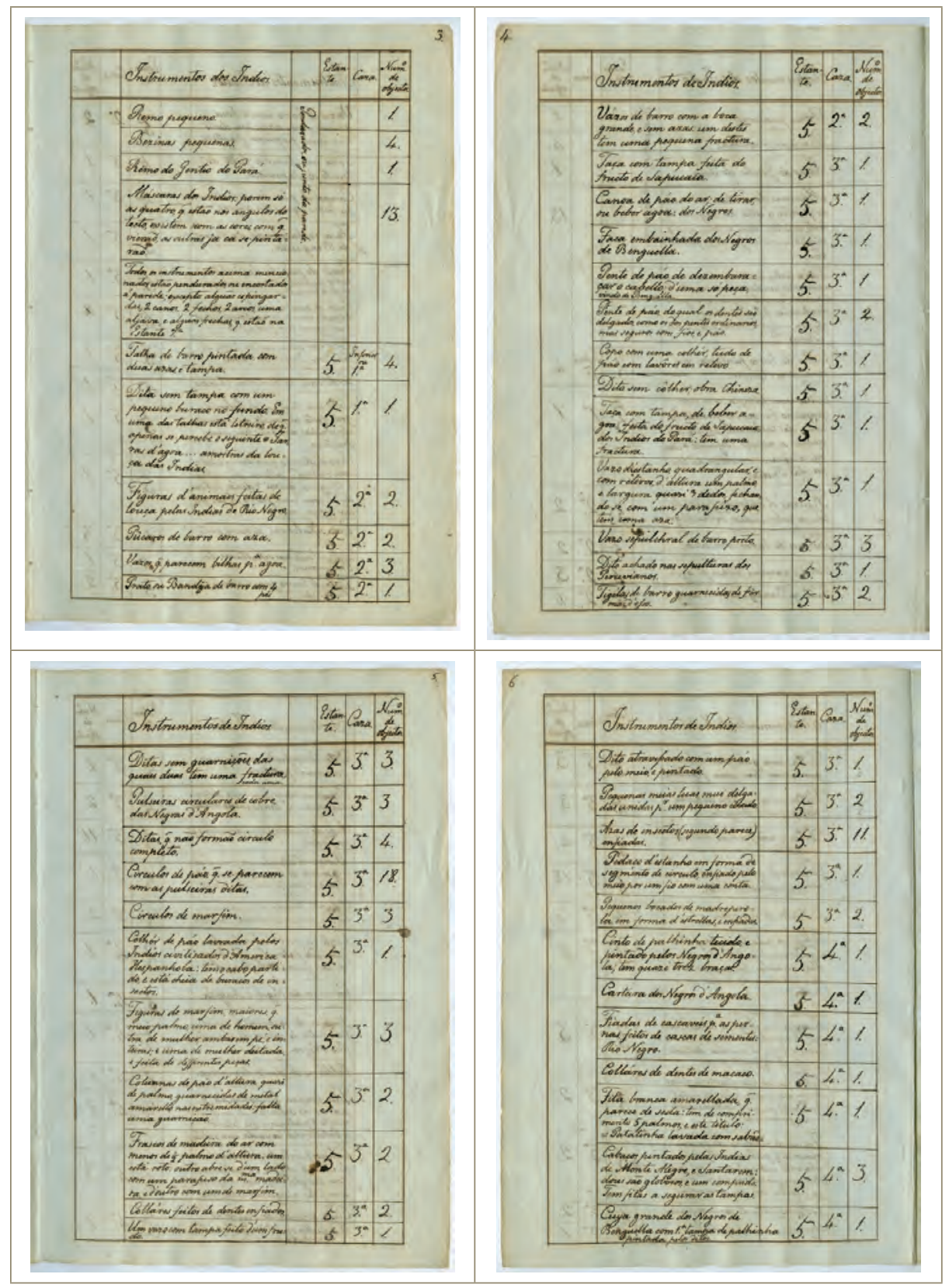




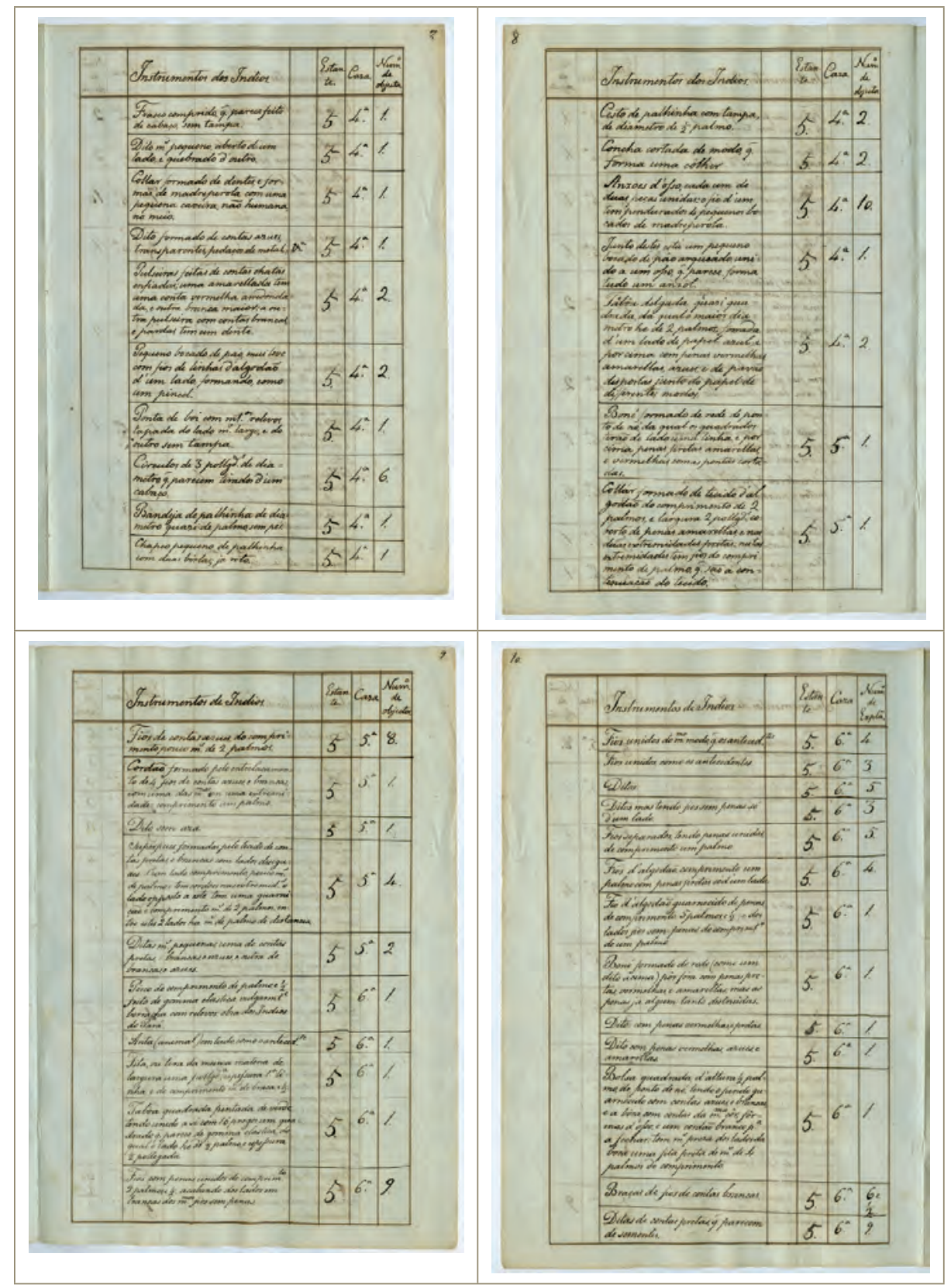



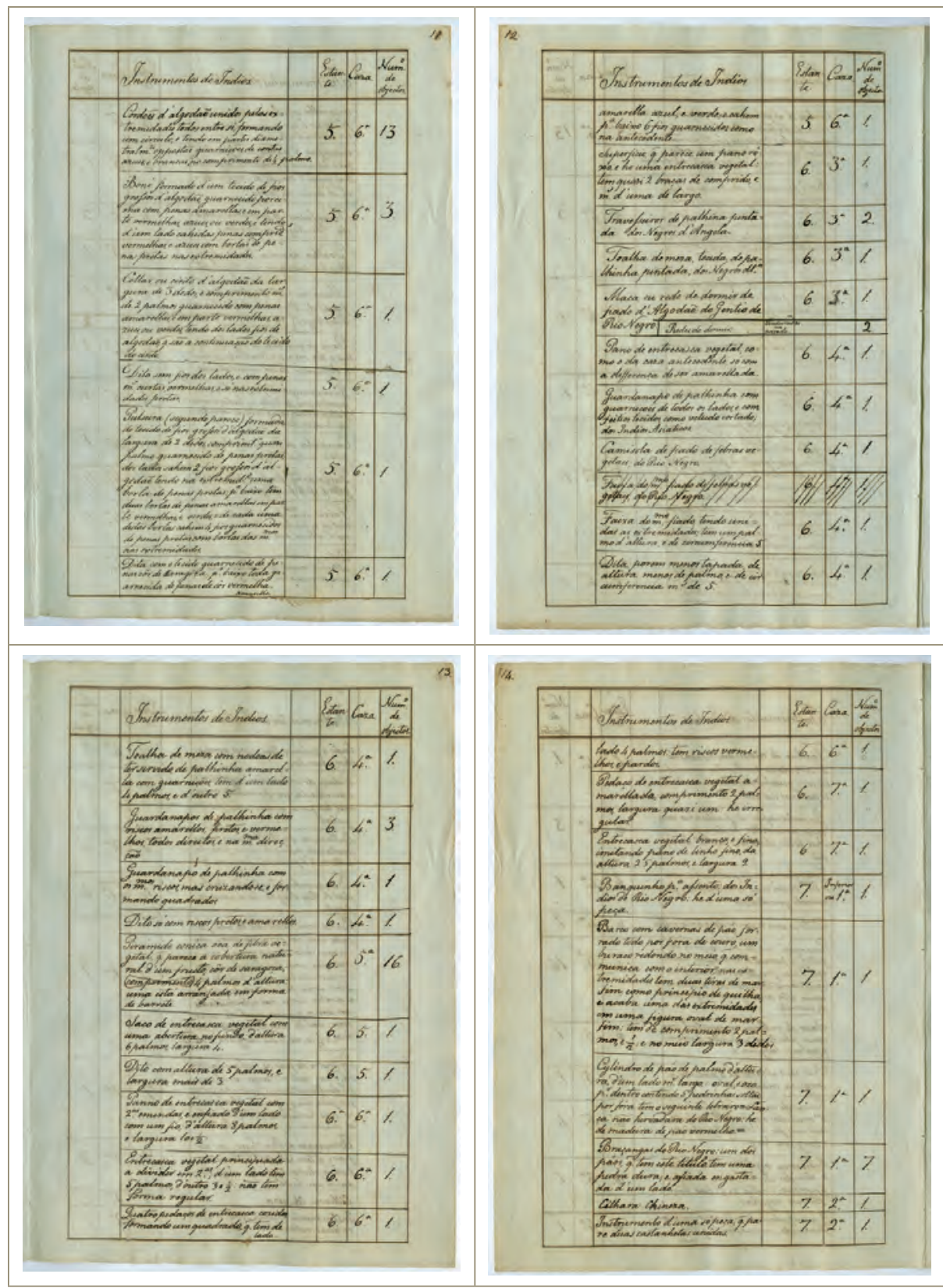


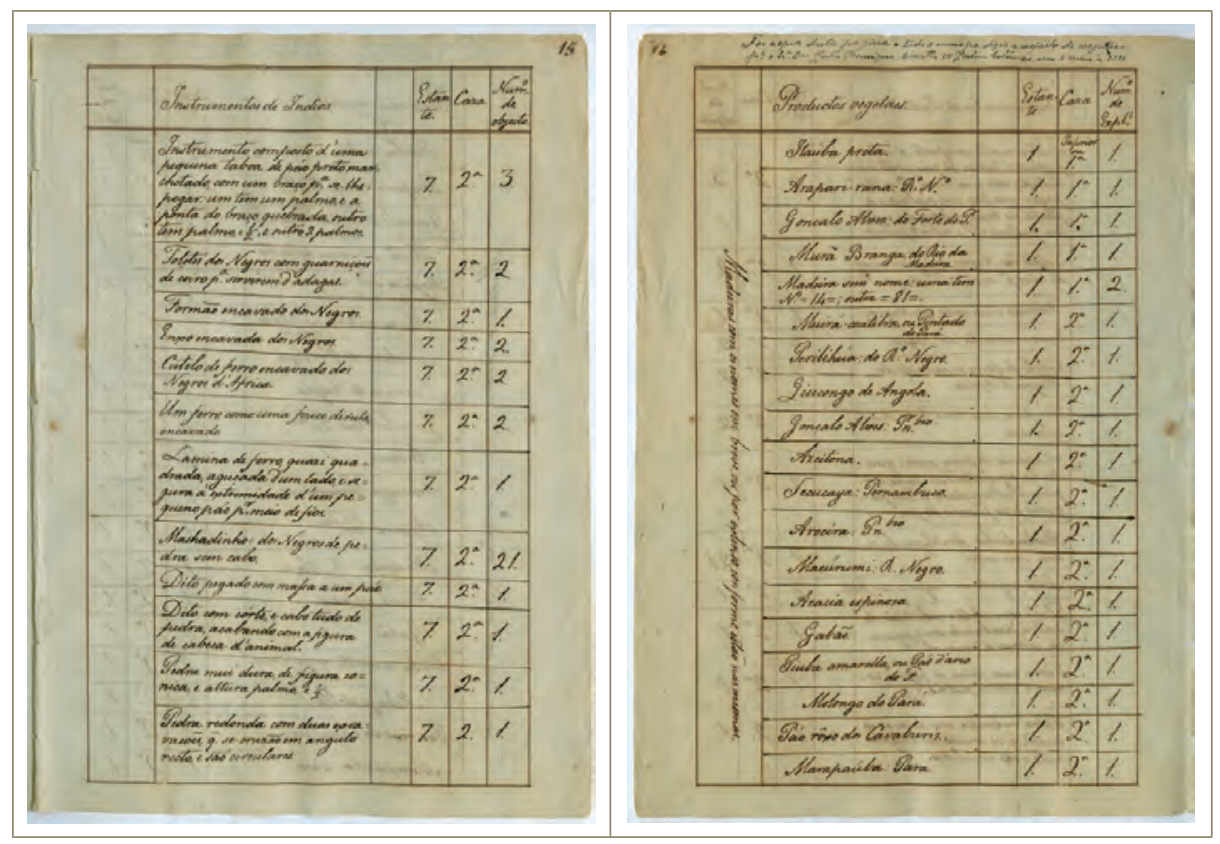


ANEXo N. ${ }^{\circ}$ 2. INVENTÁRIo De $1850^{27}$

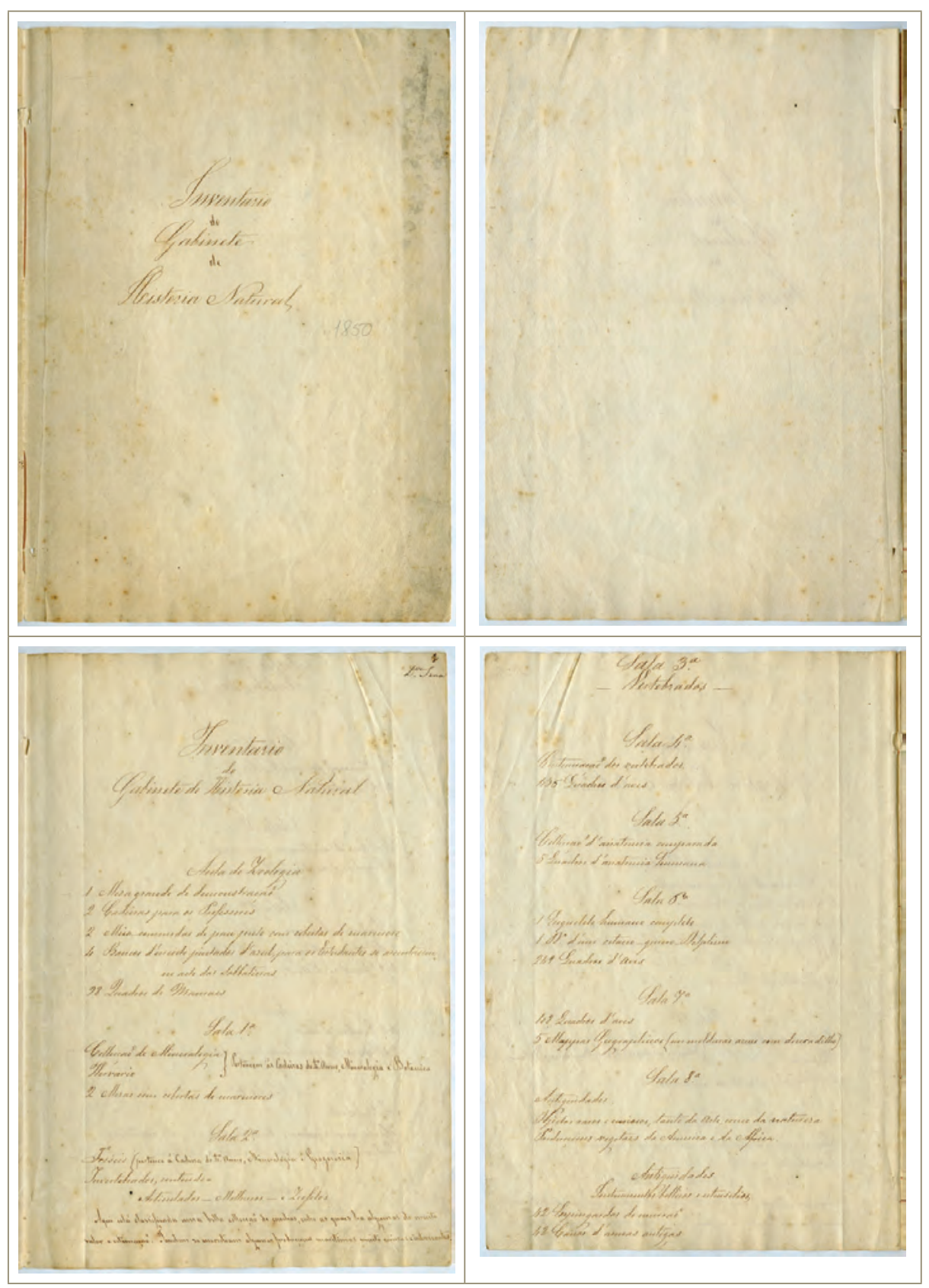

${ }^{27}$ Documento manuscrito existente no arquivo das colecções de antropologia, Museu da Ciência da Universidade de Coimbra. 


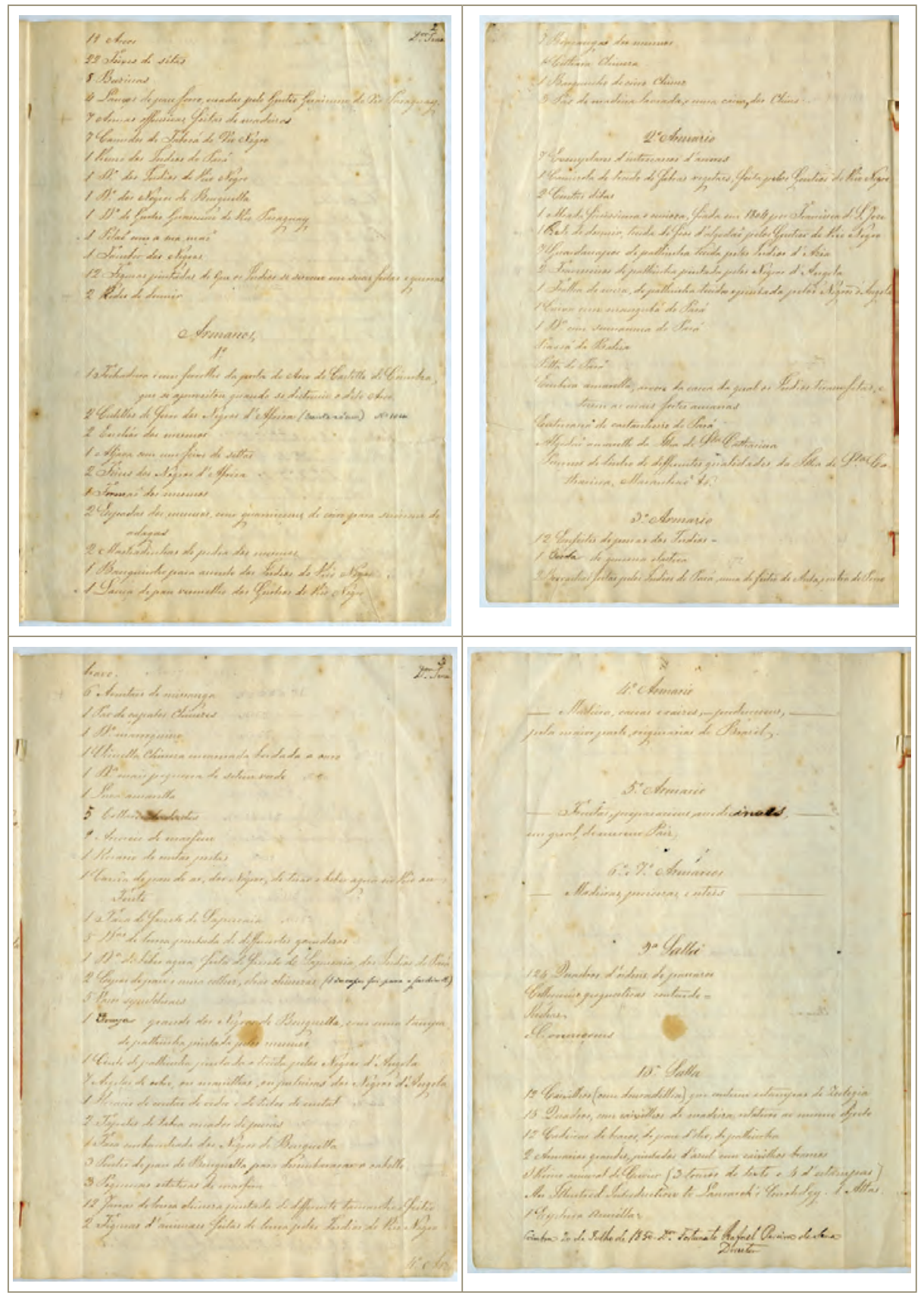




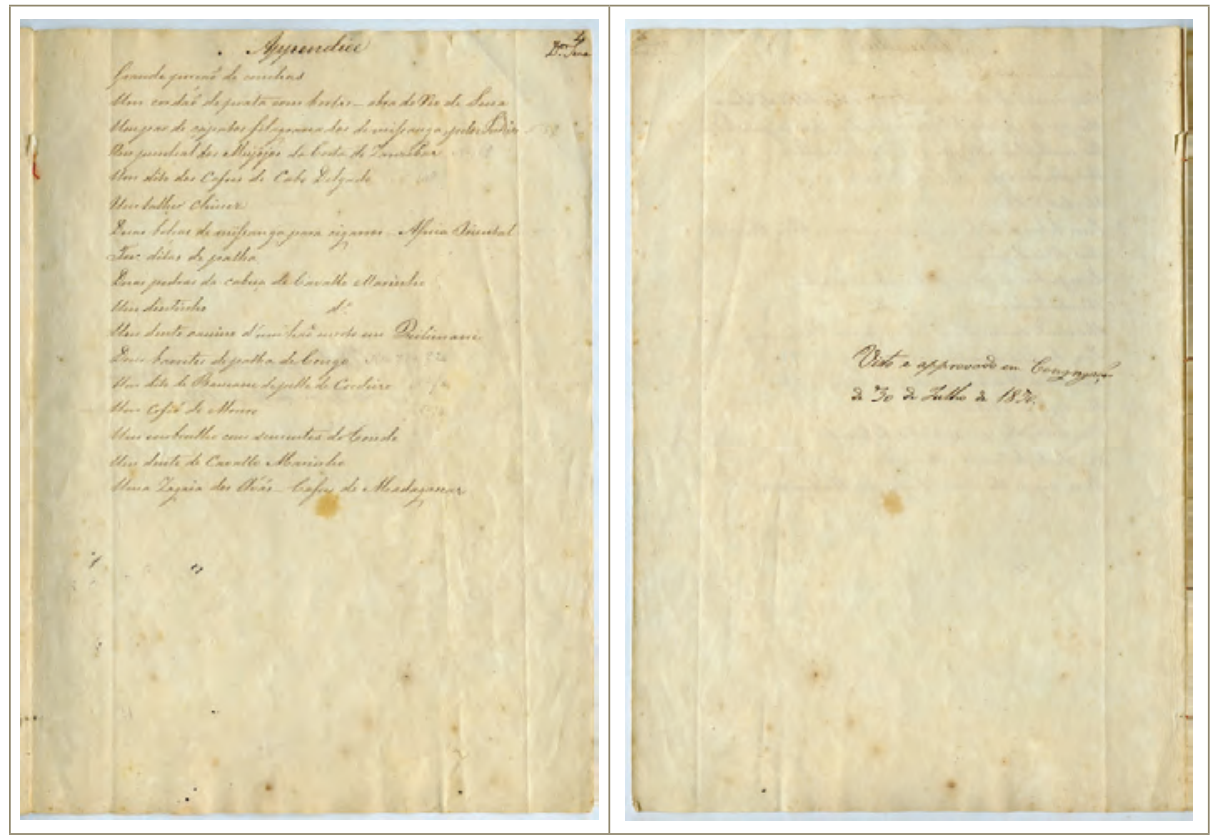


ANEXo N. ${ }^{\circ}$ 3. INVENTÁRIO DE $1881^{28}$

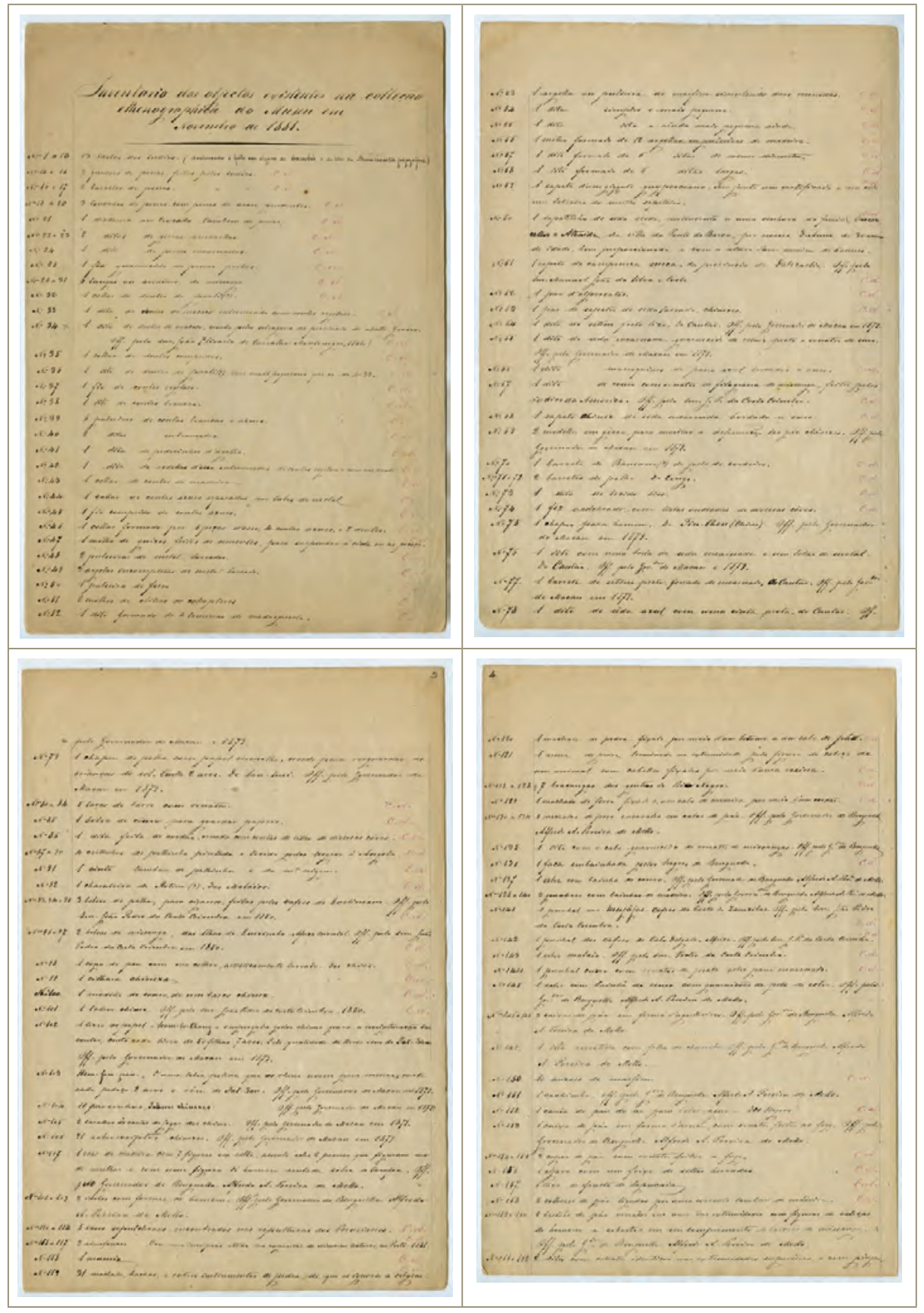

${ }^{28}$ Documento manuscrito existente no arquivo das colecçôes de antropologia, Museu da Ciência da Universidade de Coimbra. 


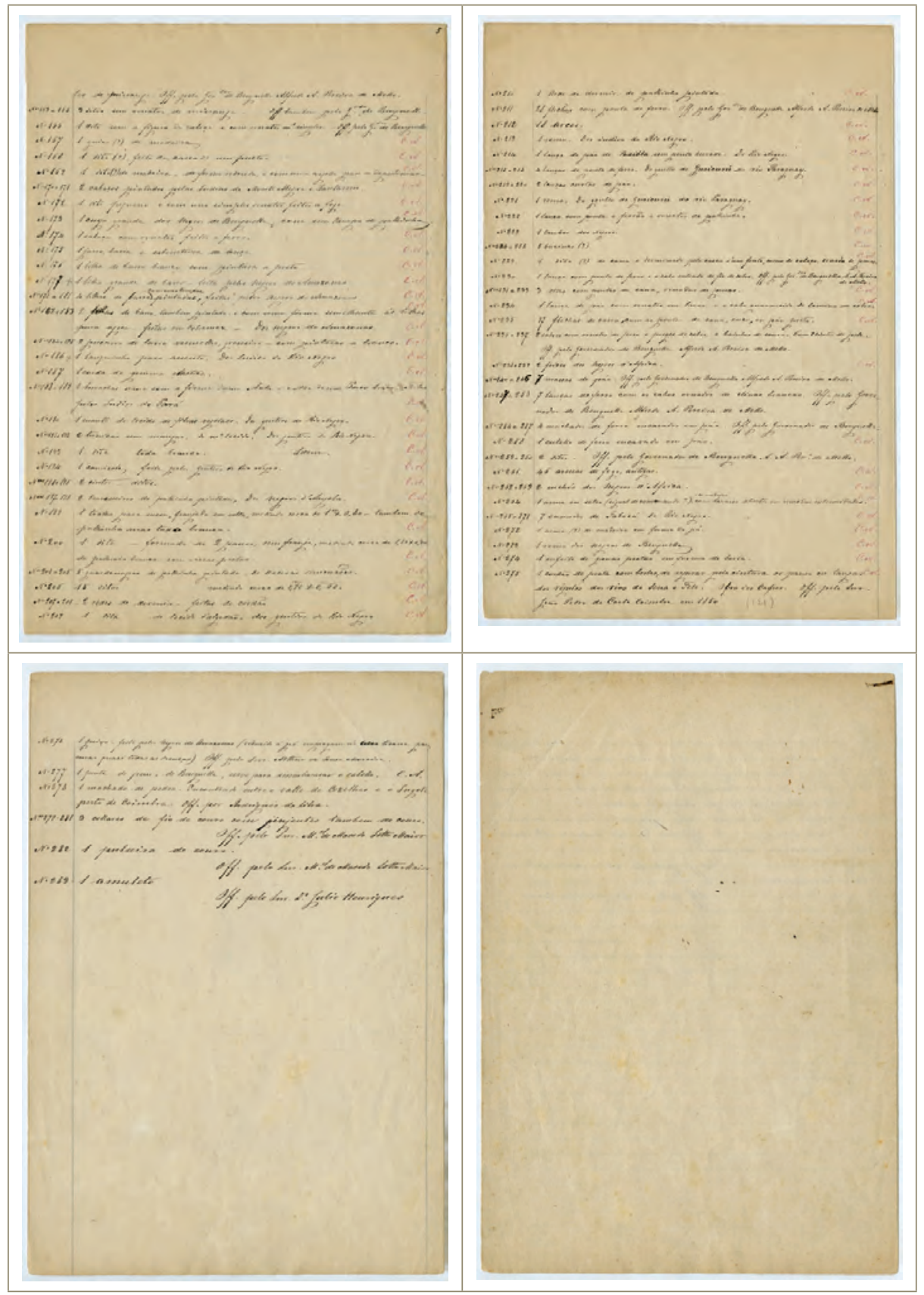


Anexo N. ${ }^{\circ} 4$ - Quadro das Colecções Incorporadas na Secção de Antropologia do Museu de História Natural da Universidade de Coimbra até 1933

(Pela sua importância foram consideradas algumas incorporações embora se desconheça a identidade do coleccionador)

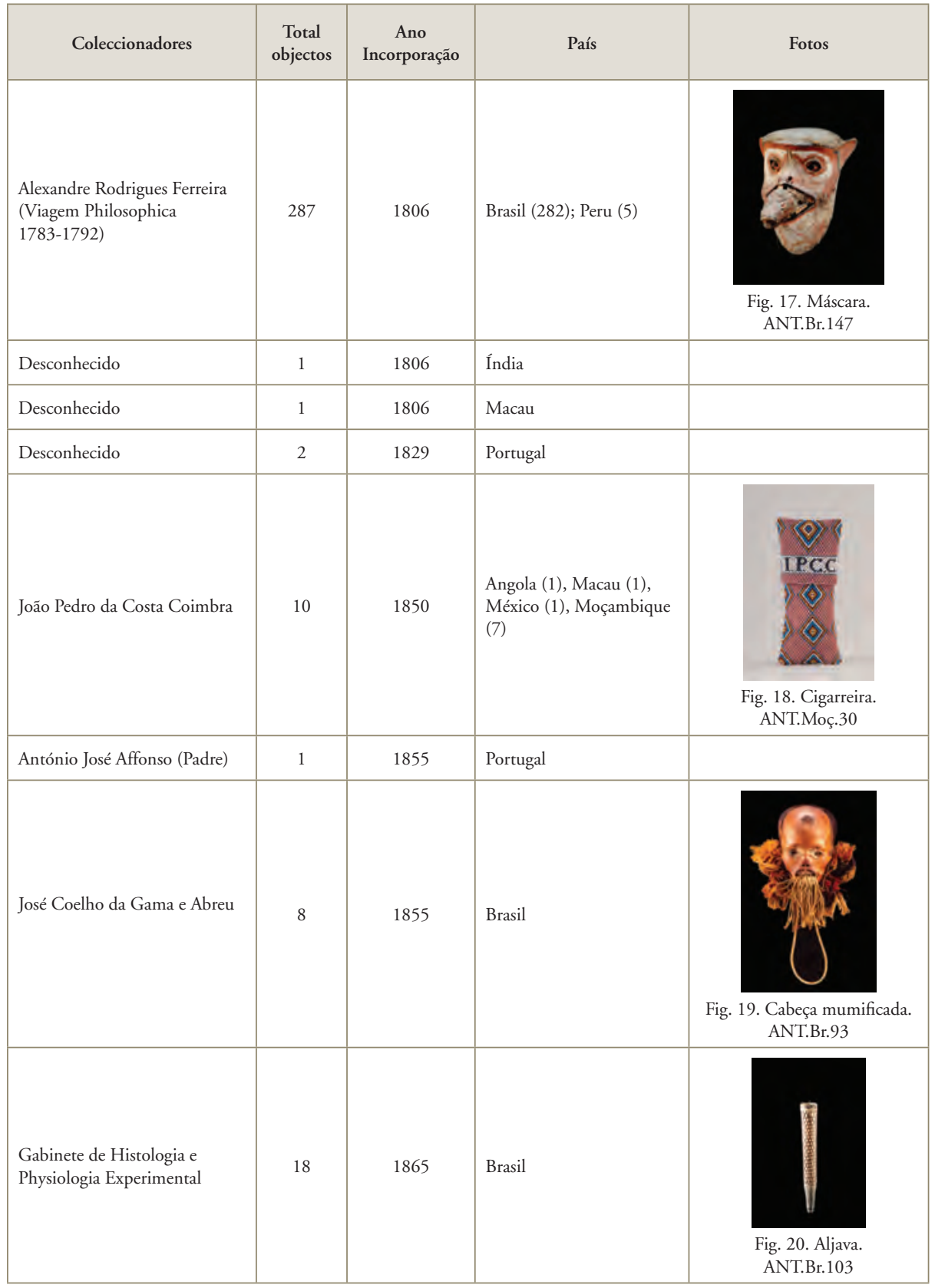




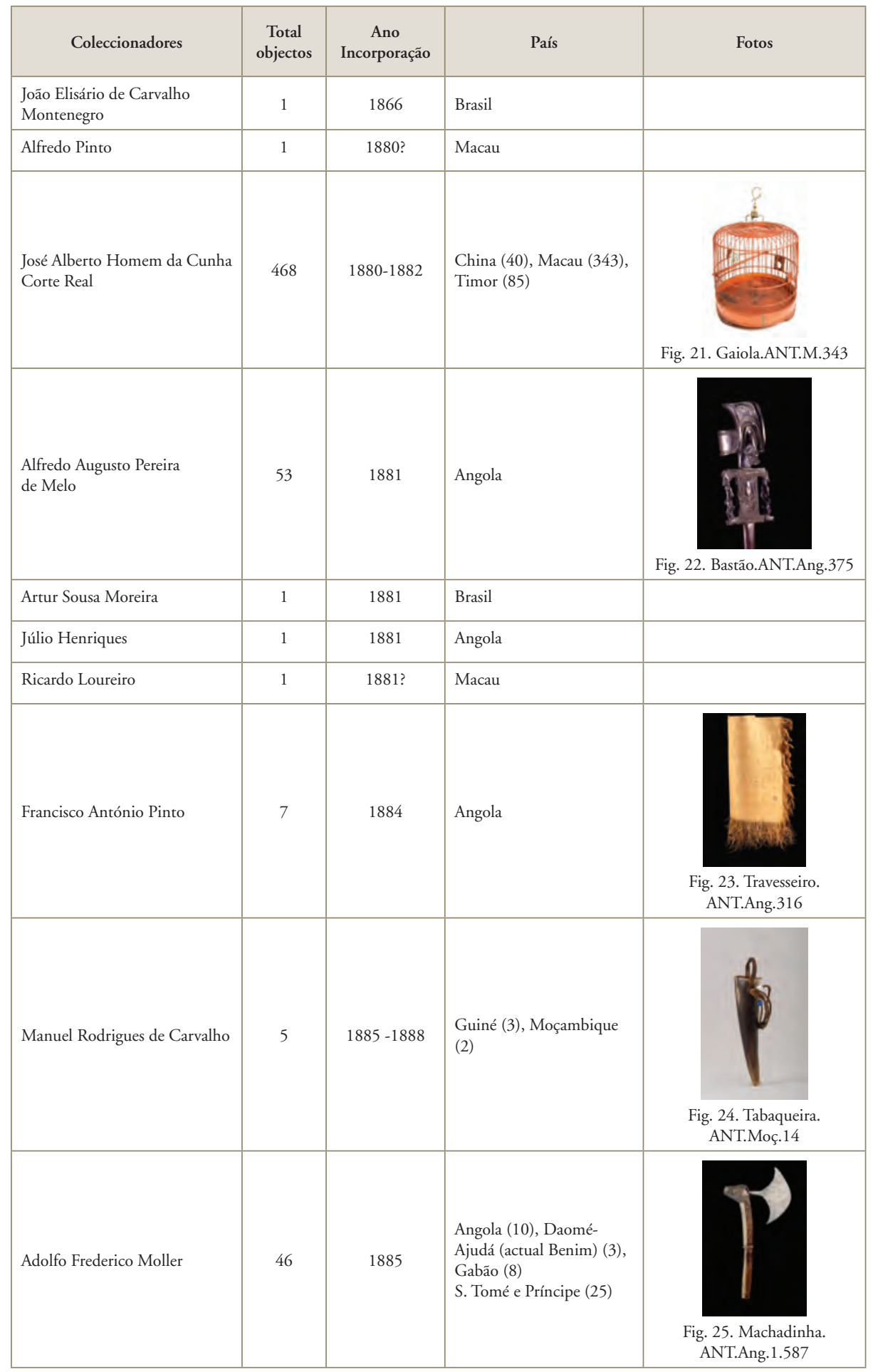




\begin{tabular}{|c|c|c|c|c|}
\hline Coleccionadores & $\begin{array}{c}\text { Total } \\
\text { objectos }\end{array}$ & $\begin{array}{c}\text { Ano } \\
\text { Incorporação }\end{array}$ & País & Fotos \\
\hline Cipriano Jardim & 4 & $1886 ?$ & Timor & \\
\hline Elísio F. Amorim Pessoa & 1 & 1886 & Timor & \\
\hline Dimas Filgueira & 6 & 1889 & Chile (5), Peru (1) & \\
\hline A. J. Tiago & 1 & 1894 & S. Tomé e Príncipe & \\
\hline José Coelho da Serra & 2 & $1894-1896$ & Cabo Verde & \\
\hline Benjamim S. Teixeira & 28 & 1894 & Moçambique & Fig. 26. Cálice.ANT.Moç.292 \\
\hline Desconhecido & 1 & 1894 & Angola & \\
\hline Francisco Mendes Lopes & 1 & 1894 & S. Tomé e Príncipe & \\
\hline João Paes de Vasconcellos & 9 & 1894 & Cabo Verde & $\begin{array}{l}\text { Fig. 27. Amostra de colcha. } \\
\text { ANT.CV.2 }\end{array}$ \\
\hline Adriano dos Santos Gil & 1 & 1896 & Angola & \\
\hline Alberto Correia & 562 & $1896-1897$ & $\begin{array}{l}\text { Angola (545), Gabão (1), } \\
\text { Guiné (2), Moçambique } \\
\text { (8), S.Tomé e Príncipe (3) }\end{array}$ & 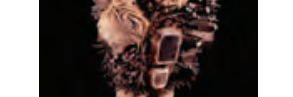 \\
\hline Alberto Saraiva da Costa & 9 & 1896 & Angola & \\
\hline Almada Negrellos & 3 & 1896 & S. Tomé e Príncipe & \\
\hline Amaral e Irmão & 5 & 1896 & S. Tomé e Príncipe & \\
\hline André Caita & 7 & 1896 & Angola & \\
\hline António José do Nascimento & 1 & 1896 & Angola & \\
\hline António Maria Júdice da Costa & 3 & 1896 & Angola & \\
\hline Banco Nacional Ultramarino & 10 & 1896 & S. Tomé e Príncipe & \\
\hline
\end{tabular}




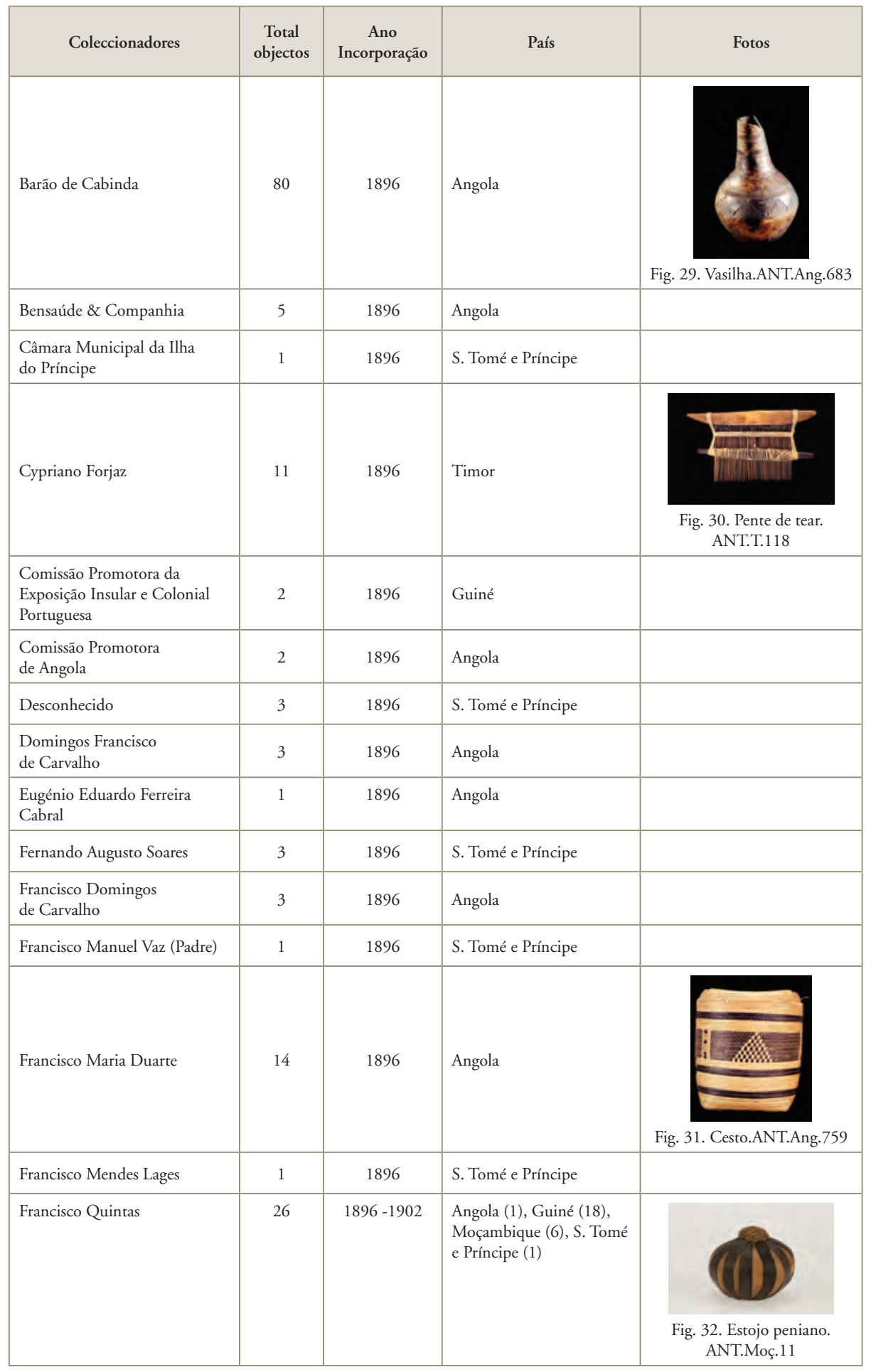




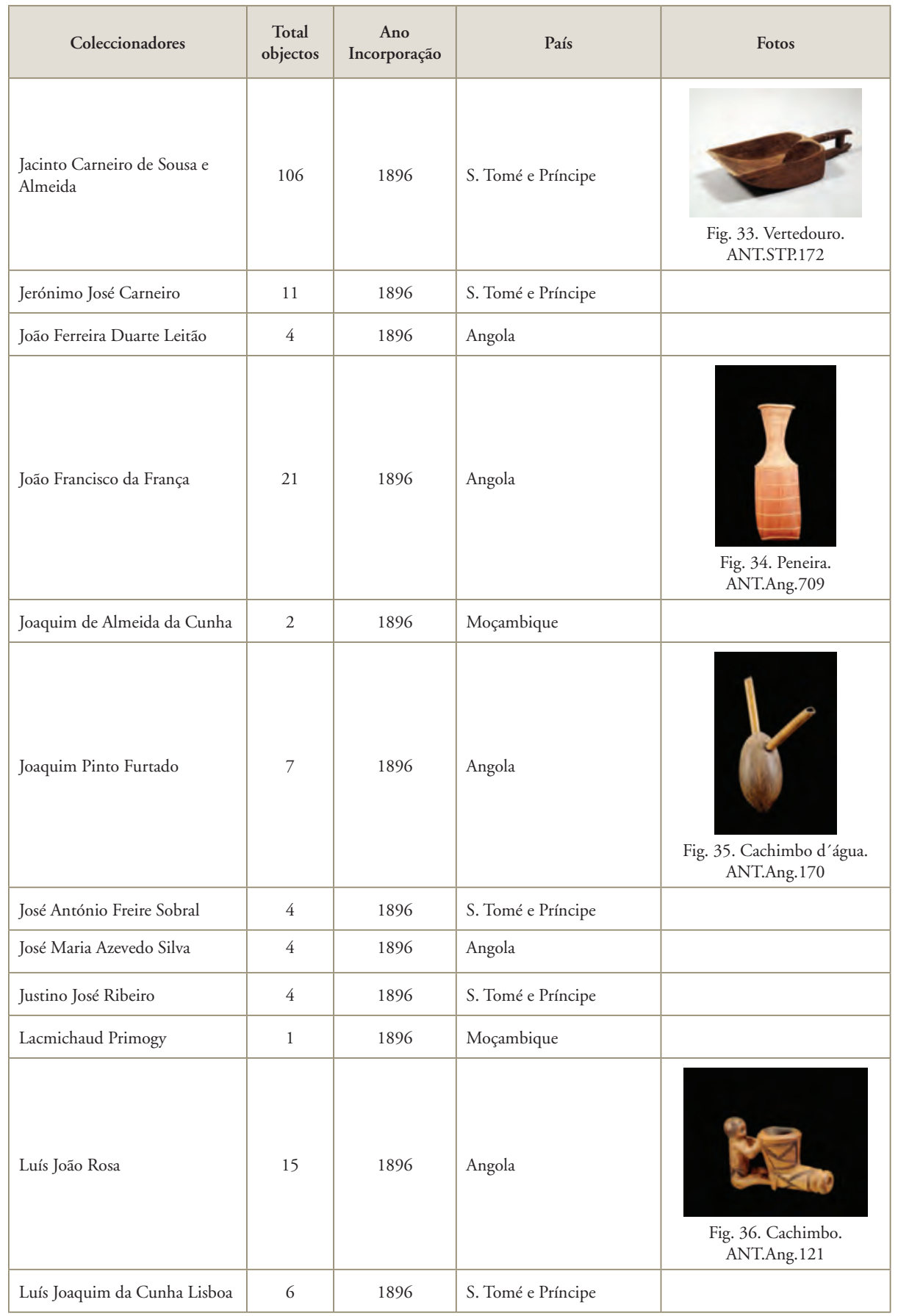




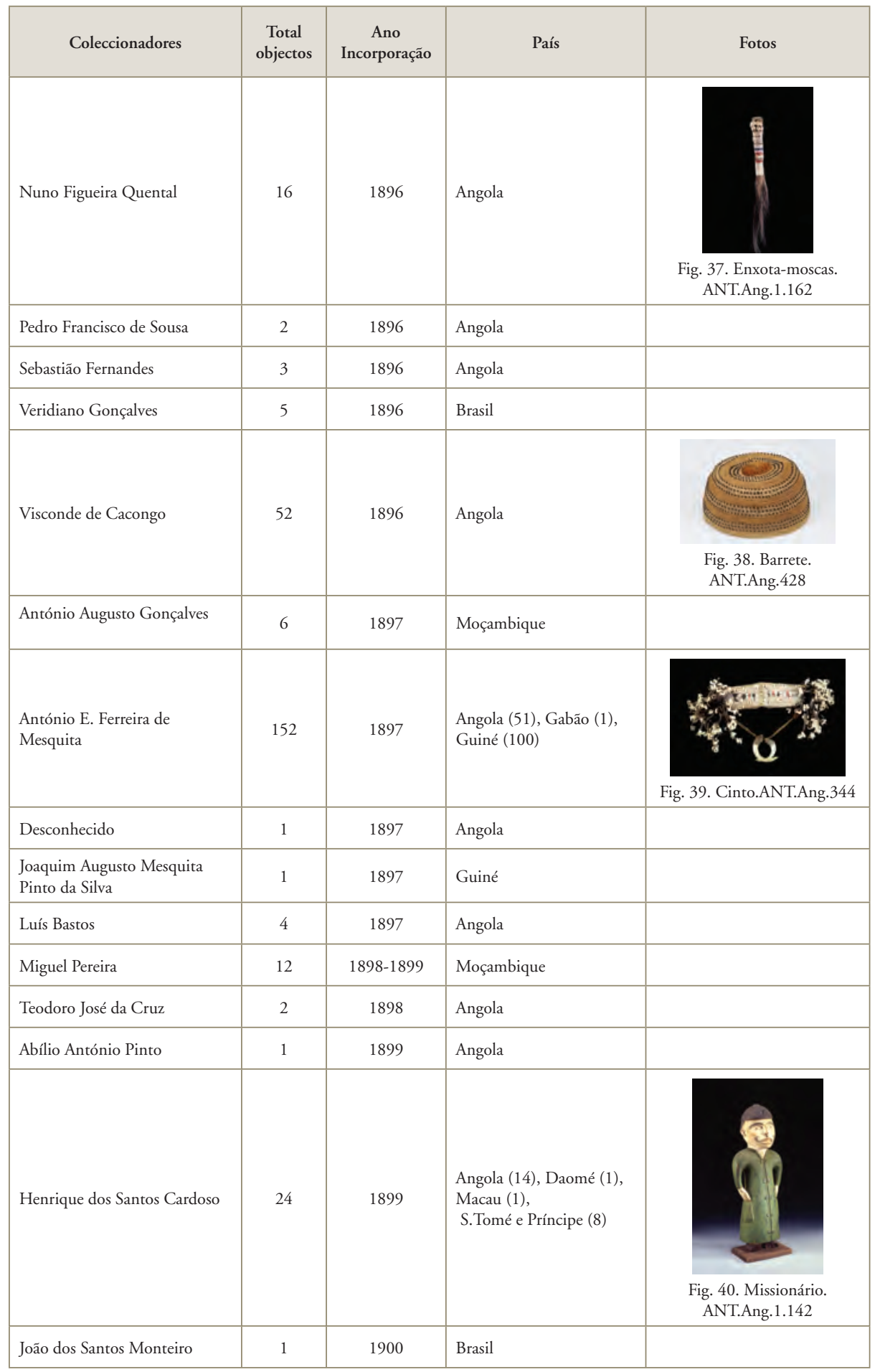




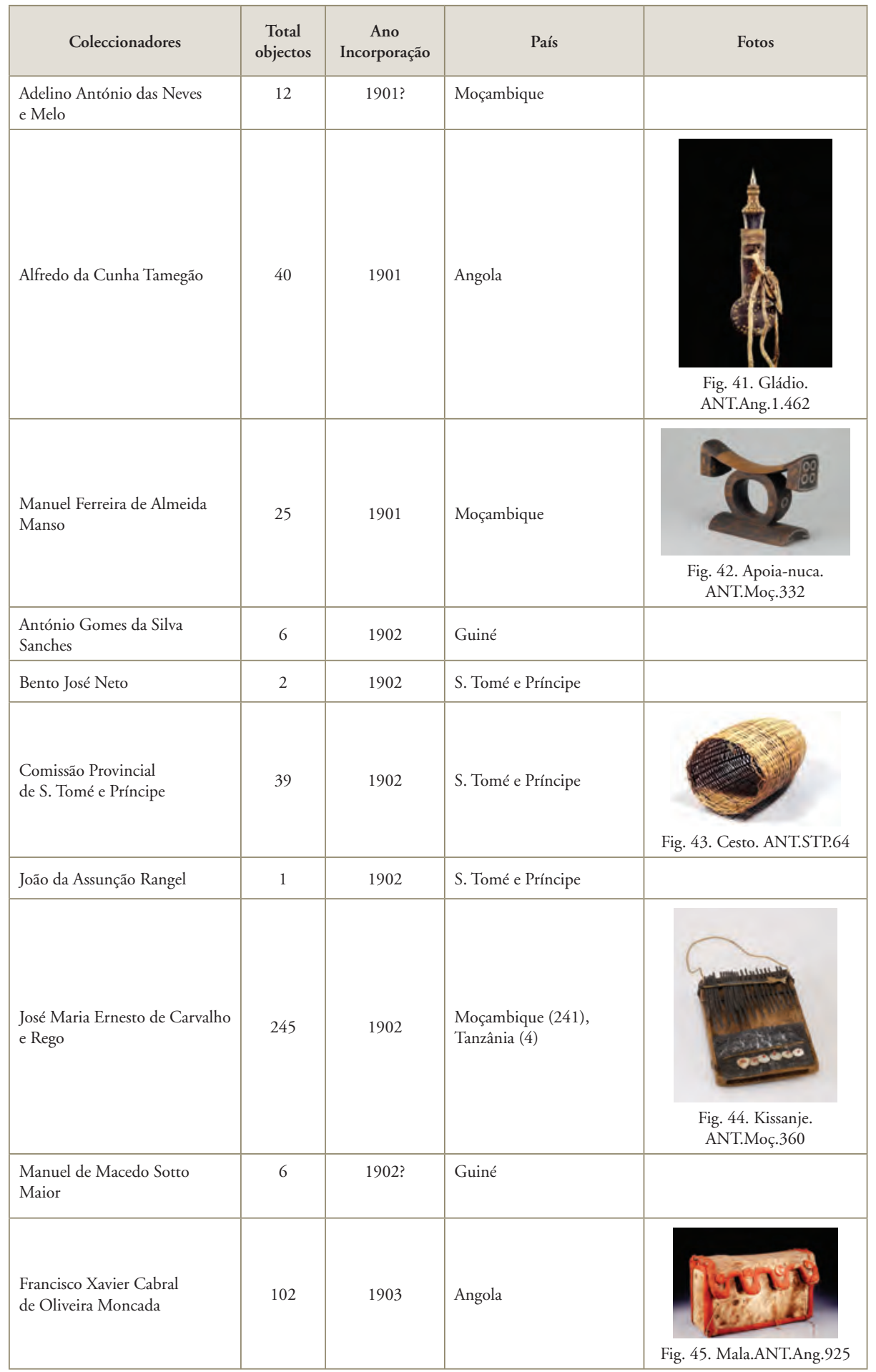




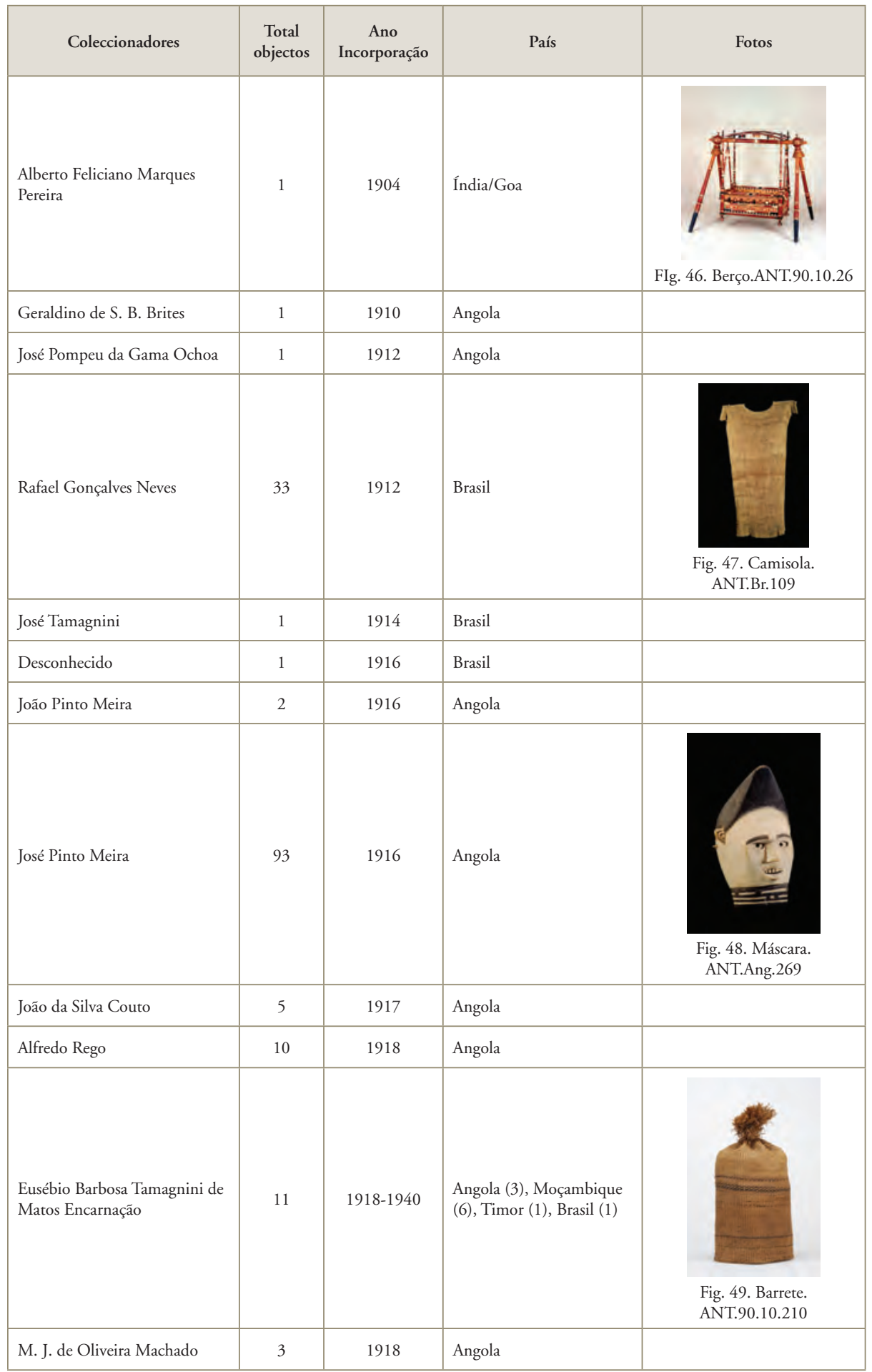




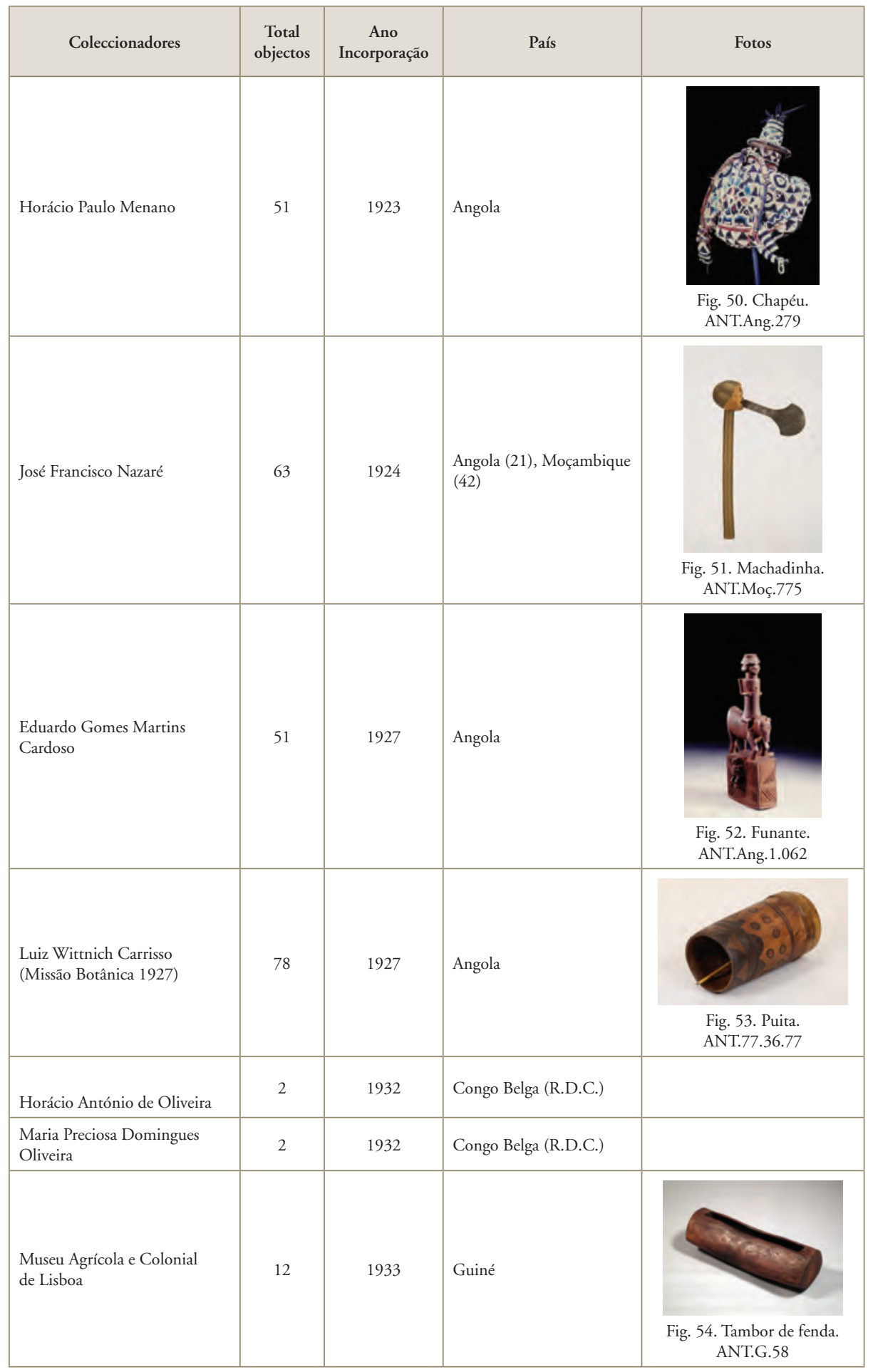




\section{Créditos Fotográficos:}

A. Bobone - Figura 12

Ana Rita Amaral - Figuras 1, 2, 3, 4

António E. F. de Mesquita - Figura 11

Carlos Acciaioli da Fonseca Themudo - Figura 13

Carlos Barata - Figuras 5, 6, 7, 8, 10, 14, 17, 19, 20, 22, 23, 25, 27, 28, 29, 30, 31, 34, 35, 36, 37, 39, 40, 41, $45,47,48,50,52$

Gilberto Pereira - Figuras 9, 16, 33, 43, 54

José Meneses - Figuras 18, 24, 26, 32, 38, 42, 44, 46, 49, 51, 53

Luís W. Carrisso - Figura 15

Sérgio Azenha - Figura 21 